Article

\title{
Discovery of New Apoptosis-Inducing Agents for Breast Cancer Based on Ethyl 2-Amino-4,5,6,7-Tetra Hydrobenzo[b]Thiophene-3-Carboxylate: Synthesis, In Vitro, and In Vivo Activity Evaluation
}

\author{
Emad M. Gad ${ }^{1, *}$, Mohamed S. Nafie ${ }^{1}{ }^{\circledR}$, Elsayed H. Eltamany ${ }^{1}$, Magdy S. A. G. Hammad ${ }^{1}$, \\ Assem Barakat ${ }^{2,3}$ (D) and Ahmed T. A. Boraei ${ }^{1, *}$ \\ 1 Chemistry Department, Faculty of Science, Suez Canal University, Ismailia 41522, Egypt; \\ Mohamed_nafie@science.suez.edu.eg (M.S.N.); s.eltamany51@yahoo.com (E.H.E.); \\ magdy_hammad83@yahoo.com (M.S.A.G.H.) \\ 2 Chemistry Department, College of Science, King Saud University, P.O. Box 2455, Riyadh 11451, Saudi Arabia; \\ ambarakat@ksu.edu.sa \\ 3 Chemistry Department, Faculty of Science, Alexandria University, P.O. Box 426, Ibrahimia, \\ Alexandria 21321, Egypt \\ * Correspondence: emad_gad@science.suez.edu.eg (E.M.G); ahmed_tawfeek83@yahoo.com (A.T.A.B.)
}

Received: 26 April 2020; Accepted: 25 May 2020; Published: 28 May 2020

check for updates

\begin{abstract}
A multicomponent synthesis was empolyed for the synthesis of ethyl 2-amino-4,5,6,7tetrahydrobenzo[b]thiophene-3-carboxylate 1 . An interesting cyclization was obtained when the amino-ester 1 reacted with ethyl isothiocyanate to give the benzo[4,5]thieno[2,3-d][1,3]thiazin-4-one 3 . Acylation of the amino-ester $\mathbf{1}$ with chloroacetyl chloride in DCM and $\mathrm{Et}_{3} \mathrm{~N}$ afforded the acylated ester 4. The amino-ester 1 was cyclized to benzo[4,5]thieno[2,3-d]pyrimidin-4(3H)-one 8, which was reacted with some alkylating agents leading to alkylation at nitrogen 9-13. Hydrazide 14 was utilized as a synthon for the synthesis of the derivatives 15-19. Chloro-thieno[2,3-d]pyrimidine 20 was synthesized and reacted with the hydrazine hydrate to afford the hydrazino derivative 21, which was used as a scaffold for getting the derivatives 22-28. Nucleophilic substitution reactions were used for getting the compounds 29-35 from chloro-thieno[2,3- $d$ ]pyrimidine 20. In the way of anticancer therapeutics development, the requisite compounds were assessed for their cytotoxicity in vitro against MCF-7 and HepG-2 cancer cell lines. Twelve compounds showed an interesting antiproliferative potential with $\mathrm{IC}_{50}$ from 23.2 to $95.9 \mu \mathrm{M}$. The flow cytometric analysis results showed that hit 4 induces the apoptosis in MCF-7 cells with a significant $26.86 \%$ reduction in cell viability. The in vivo study revealed a significant decrease in the solid tumor mass (26.6\%) upon treatment with compound 4. Moreover, in silico study as an agonist for inhibitors of JAK2 and prediction study determined their binding energies and predicted their physicochemical properties and drug-likeness scores.
\end{abstract}

Keywords: benzo[b]thiophene; pyrimidinone; alkylation; MCF-7; HepG-2; JAK2 inhibitor

\section{Introduction}

The development and discovery of high efficacy anticancer agents by many molecular oriented strategies and techniques have increased in the last decades [1]. Globcan in 2018 provided a statistical report worldwide on the global burden of cancer, which shows 18.1 million new cancer incidences and 9.6 million mortalities. The female breast cancer is the second type of cancer, leading to death with $11.6 \%$. The statics show that in every $8-10$ women, one gets developed with breast cancer. Moreover, the fourth fatal cancer mortality is liver cancer with $8.2 \%$ [2]. 
There are several reasons for the tremendous growth of cancer mortality and new cases worldwide due to an increasing number of the population, high rate of aging, as well as prevalence changes and distribution of the risk factor for cancer linked with socioeconomic development. More specifically, the risk factors responsible for the development of breast cancer are reproductive factors (e.g., late menopause, multiparty, premature menarche, do not breastfeed), genetic factors (if her mother has breast cancer), lifestyle and dietary related factors (e.g., obesity, drinking, and smoking), and environmental factors (exogenous estrogen exposure for a long time). There are several types of breast cancer treatments including chemotherapy, radiotherapy, surgery, immune, and hormone therapy but still these treatments have diverse side effects. The urgent need to discover and develop a high efficacy anticancer therapy is highly challenged. Several therapeutic potentials have been discovered for cancer treatment with different targets; one of the most promising targets for cancer therapies is the JAK family [3]. JAK family members (JAK1, JAK2, JAK3, and TYK2) play an important role in the pathogenesis of many immunological disorders and cellular malignancies. The activity of JAK kinase was described in a series of abnormal cell proliferation of the hematologic neoplasias, including B-cell non-Hodgkin's and Hodgkin's lymphomas, myeloid leukemias, and lymphoid [4]. One of the most molecular targets and techniques for antiproliferative and pro-apoptotic effects are to design potential JAK inhibitors.

Fused heterocycles, based on pyrimidine scaffolds, have gained significant attention due to a wide range of pharmacological applications [5]. Especially, thienopyrimidines have been discovered as anticancer agents [6,7], EGFR kinase inhibitors (compound I, IC $\mathrm{I}_{50}=2.6$ [8]; compound II, $\mathrm{IC}_{50}=0.008$, and compound III, IC ${ }_{50}=0.007 \mu \mathrm{M}$, respectively) [9], compound IV selective against HepG-2 $\left(\mathrm{IC}_{50}=14.9 \mu \mathrm{M}\right)[10]$, compound $\mathbf{V}$ selective against the MCF-7 breast cancer line $\left(\mathrm{IC}_{50}=0.10 \mu \mathrm{M}\right)$ [11], and tyrosine kinase inhibitors (compound VI) [12]. TargeGen, Inc. et al. have been designed as an JAK2 inhibitor based on the core structure of anilinopyrimidine, and the cell proliferation assay has shown the $\mathrm{EC}_{50}=3 \mathrm{nM}$ in a JAK2 V617F (compound VI) [13]. The benzo[b]-thiophene scaffold plays a crucial rule for many STAT3 inhibitors $[14,15]$. Additionally, the substituted cycloalkyl[ $b]$ thiophene core structure possessed a cytotoxic activity [16], also exhibited biological activities such as the AChE inhibitor [17], I3-AG85 inhibitor (compound VIII) [18], as well as the HCV replication inhibitor (compound IX, Figure 1) [19], antiviral [20], anti-inflammatory [21,22], antibacterial [23,24], and antitumor activities [25-29]. In the proceeding text, we have synthesized a set of compounds based on the cycloalkyl $[b]$ thiophene with different hybrids tethered pharmacophoric/functional groups diversity (Figure 1). The target hybrids were examined against two cancer cell lines (breast cancer MCF-7 and liver cancer HepG-2), followed by an in vivo study along with the flow cytometric analysis for the most active member were also carried out. Finally, an in silico molecular docking study such as the JAK2 inhibitor determined their binding energies and predicted their physicochemical properties and drug-likeness scores. 


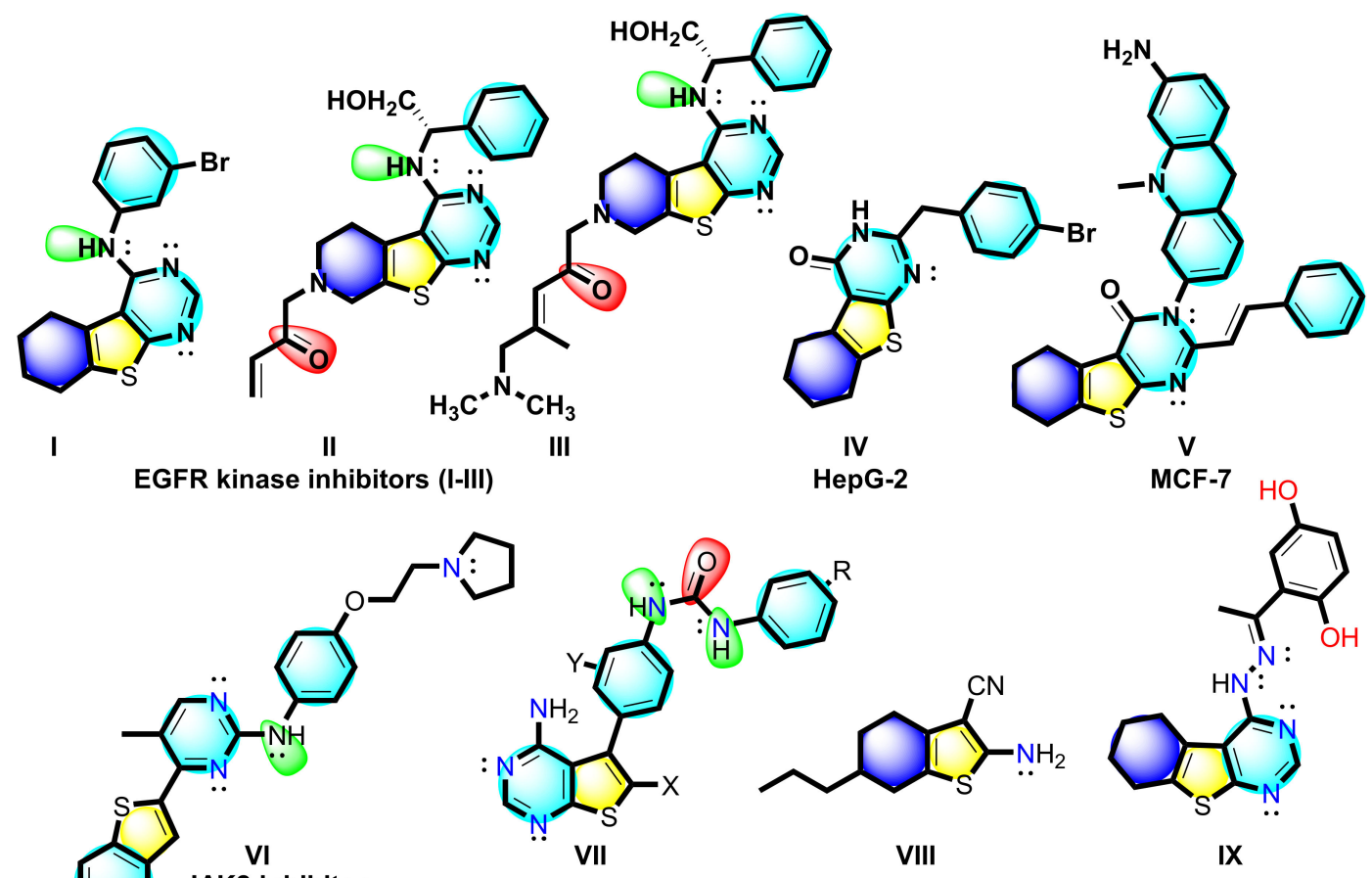
JAK2 inhibitor tyrosine kinase inhibitors

I3-AG85 inhibitors HCV replication inhibitor

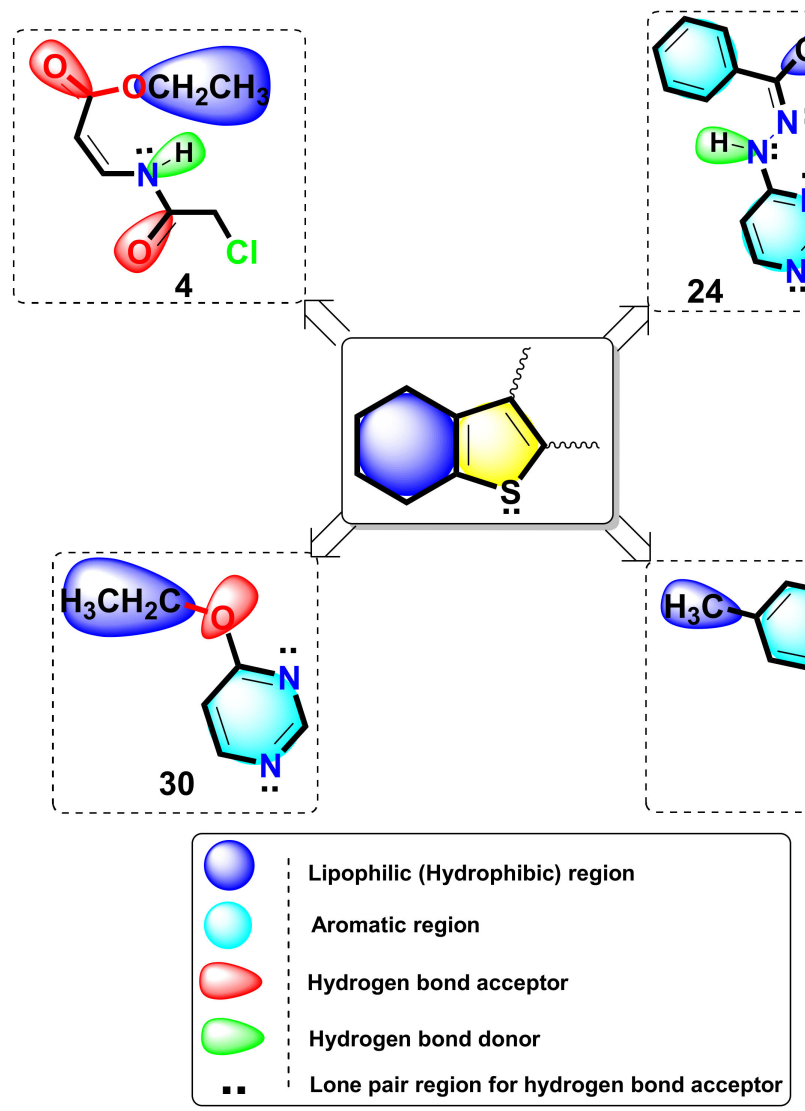

Figure 1. Biologically active compounds based on benzo[b]-thiophene and cycloalkyl $[b]$ thiophene and pharmacophoric/functional groups relationship. 


\section{Results and Discussion}

\subsection{Chemistry}

\subsubsection{Synthesis}

The benzo[ $b]$ thiophene analogue $\mathbf{1}$ was synthesized in high yield using the multicomponent strategy from ethyl cyanoacetate, cyclohexanone, sulfur and triethylamine in ethanol. The amino-ester 1 was reacted with phenyl isothiocyanate in ethanol containing $\mathrm{Et}_{3} \mathrm{~N}$ to afford the $N, N$-disubstituted thiourea derivative 2 . Whereas, when it was reacted with ethyl isothiocyanate under the same conditions, surprisingly it afforded the 2-(ethylamino)-5,6,7,8-tetrahydro-4H-benzo[4,5]thieno[2,3d] $[1,3]$ thiazin-4-one 3 (Scheme 1).<smiles>O=C1CCCCC1</smiles><smiles>CCOC(=O)CC#N</smiles><smiles>CCOC(=O)c1c(N)sc2c1CCCC2</smiles>

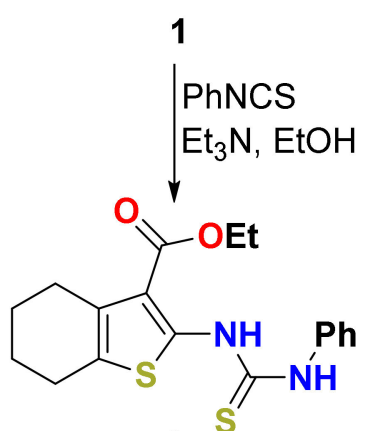

2
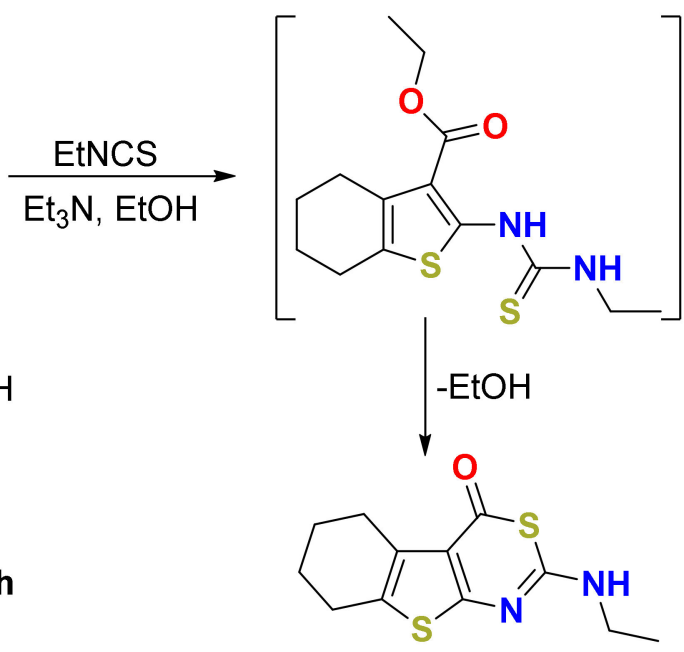

3

Scheme 1. Multicomponent synthesis of $\mathbf{1}$ and its reaction with isothiocyanates.

Acylation of the amino-ester 1 with chloroacetyl chloride in DCM and $\mathrm{Et}_{3} \mathrm{~N}$ afforded the acylated ester 4 . Compound 4 was used for the alkylation of cyclohexylamine to afford the alkylated product 5. The benzoylation of the benzo[ $b$ ]thiophene analogue $\mathbf{1}$ was done by a reaction with benzoyl chloride in benzene containing triethylamine to afford the amide $\mathbf{6}$. The reaction of $\mathbf{1}$ with benzene sulfonyl chloride in ethanol yielded the sulfonamide 7 (Scheme 2).<smiles>CCOC(=O)c1c(NC(=O)CNC2CCCCC2)sc2c1CCCC2</smiles>

Scheme 2. Synthesis of 4-7 starting from compound 1.

Cyclization of the amino-ester 1 was done by reflux with formamide for $3 \mathrm{~h}$ to give tetrahydrobenzo[4,5]thieno[2,3-d]pyrimidin-4(3H)-one 8. Michael additions of pyrimidinone 8 to acrylonitrile as the Michael acceptor in ethanol containing $\mathrm{Et}_{3} \mathrm{~N}$ led to an addition at nitrogen to give the Michael adduct 9. Alkylation of 8 with benzyl bromide, phenacyl bromide, 4-methoxyphenacyl bromide, and ethyl chloroacetate in DMF and $\mathrm{K}_{2} \mathrm{CO}_{3}$, afforded the $N$-alkylated products 10-13, respectively (Scheme 3). 

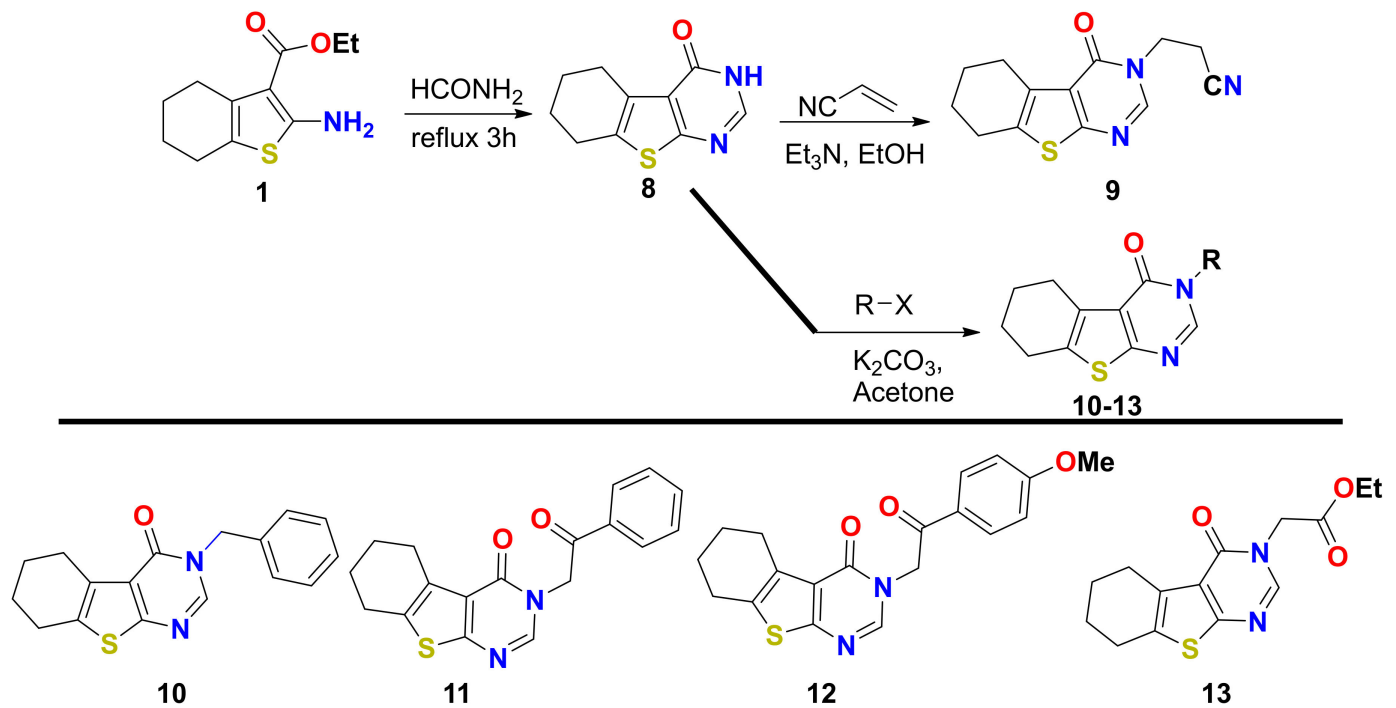

Scheme 3. Alkylation of pyrimidinone 8 with different alkylating agents.

Hydrazinolysis of the ester $\mathbf{1 3}$ to hydrazide $\mathbf{1 4}$ was done by a reaction with hydrazine hydrate in ethanol. The heating hydrazide $\mathbf{1 4}$ with phenyl isothiocyanate in dioxane for $6 \mathrm{~h}$ gives the phenyl thiosemicarbazide product 15 . The hydrazide 14 was refluxed with benzaldehyde and acetophenone in ethanol to give the hydrazones $\mathbf{1 6}$ and 17, respectively. Linking the 4-amino-1,2,4-triazolethione moiety to the benzo[4,5]thieno[2,3-d]pyrimidin-4(3H)-one system separated by a methylene spacer was achieved by a reaction with $\mathrm{CS}_{2} / \mathrm{aq}$. $\mathrm{KOH} / \mathrm{EtOH}$, to give potassium dithiocarbazate 18 , which was cyclized by a reaction with hydrazine hydrate and acidification to give $\mathbf{1 9}$ (Scheme 4).

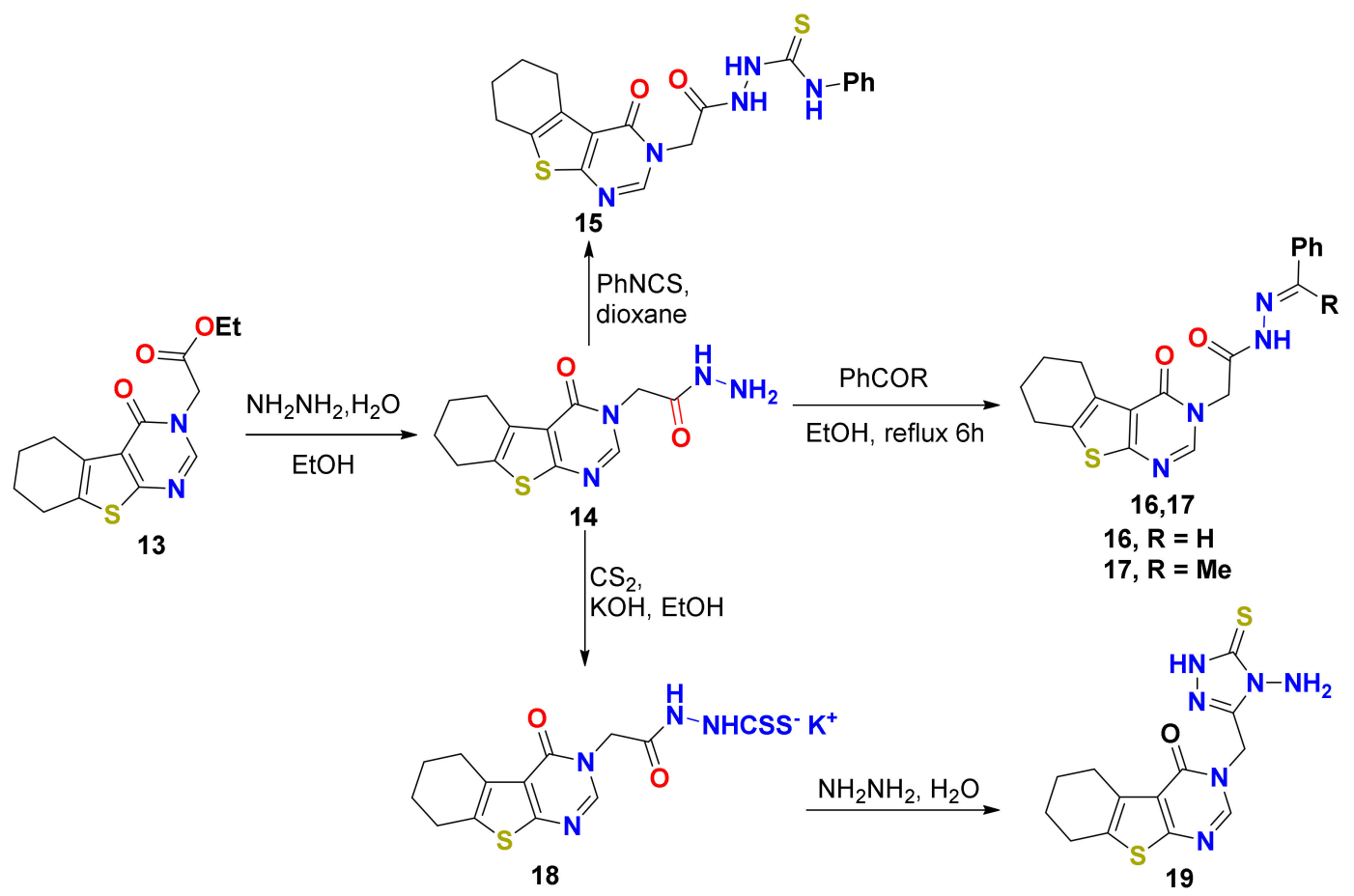

Scheme 4. Formation of hydrazones, thiosemicarbazide, and linking new 1,2,4-triazole nucleus to the system via methylene spacer 19.

The chlorination of 8 was achieved by reflux in $\mathrm{POCl}_{3}$ to yield the chloro derivative 20. A reaction of 20 with $\mathrm{NH}_{2} \mathrm{NH}_{2}$ in ethanol formed the hydrazino compound 21. The benzoylation of 21 with 
benzoyl chloride provided the $N$-benzoyl derivative 22, while the condensation of 21 with benzaldehyde and acetophenone afforded compounds 23 and 24, respectively (Scheme 5).

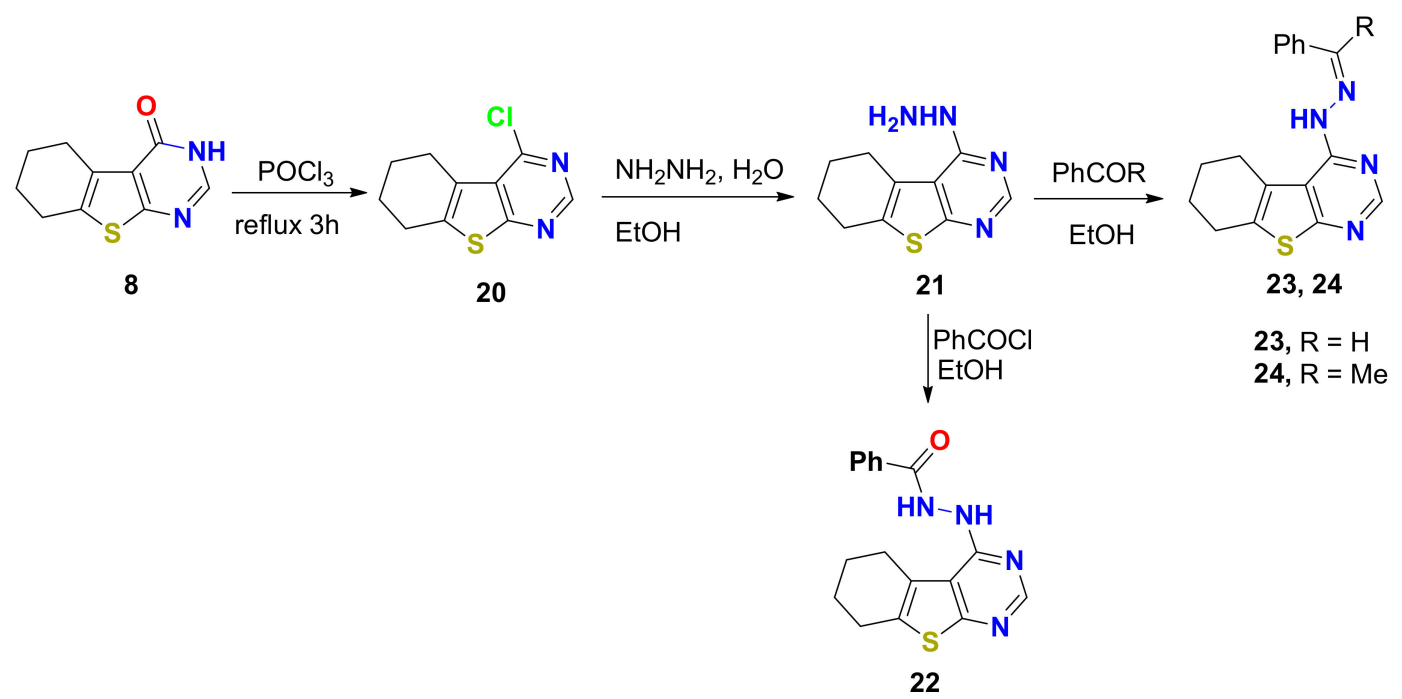

Scheme 5. Synthesis and condensation of the hydrazino derivative 21.

Cyclization of the hydrazino derivative 21 to triazolo-pyrimidines $\mathbf{2 5}$ and $\mathbf{2 6}$ was done by reflux in acetic and formic acids, respectively. The condensation of $\mathbf{2 1}$ with acetyl acetone in ethanol yielded the pyrazolo derivative 27. A reaction of $\mathbf{2 1}$ with carbon disulfide or phenyl isothiocyanate led to cyclization to the triazolo-pyrimidine-thione 28 (Scheme 6).<smiles>Cc1cc(C)n(-c2ncnc3sc4c(c23)CCCC4)n1</smiles>

27<smiles>CCOC(C)=O</smiles>
$\mathrm{EtOH}$<smiles>NNc1ncnc2sc3c(c12)CCCC3</smiles>

21
$\underset{\mathrm{Cr}}{\stackrel{\mathrm{CS}_{2}, \mathrm{KOH}, \mathrm{EtOH}}{\longrightarrow}}$ PhNCS, EtOH

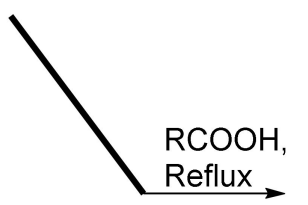

25, $\mathrm{R}=\mathrm{Me}$

26, $\mathrm{R}=\mathrm{H}$<smiles>S=C1NN=C2N=CN=C1SC1=C2CCCC1</smiles>

28<smiles>[R]c1nnc2c3c4c(sc3ncn12)CCCC4</smiles>

Scheme 6. Cyclization of the hydrazino derivative 21.

Oxygen nucleophiles such as sodium methoxide and sodium ethoxide were used to substitute the chloride of $\mathbf{2 0}$ to afford the ethers $\mathbf{2 9}$ and 30, respectively. A reaction of the chloro derivative $\mathbf{2 0}$ with nitrogen nucleophiles such as p-toluidine, benzyl amine, 4-aminobenzoic acid, and 4-acetylaniline afforded the substituted products 31-34, respectively. The reaction of the chloro derivative 20 with 2-aminobenzoic acid afforded the pyrimido-quinazolinone 35 (Scheme 7).

\subsubsection{Structural Characterization}

The ${ }^{1} \mathrm{H}$ NMR of 1 displayed the amino group as an exchangeable signal at $\delta 7.15 \mathrm{ppm}$. The ethoxy group protons $\left(\mathrm{CH}_{3} \mathrm{CH}_{2} \mathrm{O}\right)$ appeared at $\delta 4.15$ and $1.25 \mathrm{ppm} .{ }^{13} \mathrm{C}$ NMR showed the ester group carbons at $\delta 165.53(\mathrm{C}=\mathrm{O}), 59.03\left(\mathrm{OCH}_{2}\right)$, and $14.79 \mathrm{ppm}$ for $\mathrm{CH}_{3}$. The structure of 2 showed the two exchangeable signals at $\delta 11.78$ and $10.88 \mathrm{ppm}$. The thiocarbonyl and carbonyl groups were detected at $\delta 176.36$ and 166.02 ppm, respectively. Compound 3 missed the ester group signals and showed only 
the NH signal at $\delta 13.43 \mathrm{ppm}$ in addition to the ethyl group signals at 4.40 and $1.20 \mathrm{ppm}$. The ethyl group carbon signals were found at $\delta 41.08$ and $12.26 \mathrm{ppm}$, which strongly recommend the cyclic structure of 3. The acetamido group signals in 4 were found at $11.66 \mathrm{ppm}$ for $\mathrm{NH}$ and $4.57 \mathrm{ppm}$ for $\mathrm{CH}_{2} \mathrm{Cl}$. The two carbonyl groups were identified at $\delta 165.45$ and $164.23 \mathrm{ppm}$. The benzamide 6 and sulfonamide 7 NMR showed the NH signals at $\delta 12.03$ and $10.36 \mathrm{ppm}$, respectively. Due to cyclization, the structure of 8 showed the $\mathrm{NH}$ as an exchangeable signal at $12.20 \mathrm{ppm}$ and pyrimidine $\mathrm{CH}$ at $\delta 7.96 \mathrm{ppm}$. The carbonyl group was identified at $\delta 162.89 \mathrm{ppm}$. The $a z a$-Michael addition and nitrogen alkylation of $\mathbf{8}$ to produce $\mathbf{9 - 1 3}$ were deduced from the missing $\mathrm{NH}$ signal and illustrated the methylene carbon signals directly attached to the ring nitrogen $\left(\mathrm{NCH}_{2}\right)$ at $\delta 41.84,48.83,52.05$, 51.64, and $47.25 \mathrm{ppm}$, respectively. The NMR of hydride 14 showed the -CO-NHNH${ }_{2}$ group as two exchangeable signals at $\delta 9.36$ and $4.25 \mathrm{ppm}$, whereas the carbonyl carbon was identified at $\delta$ $166.55 \mathrm{ppm}$. The thiosemicarbazide 15 displayed three NH signals at $\delta 10.56,9.77$, and $9.33 \mathrm{ppm}$. The thiocarbonyl and carbonyl carbons were detected at $\delta 181.06,167.10$, and $162.50 \mathrm{ppm}$. Hydrazones 16 and 17 were confirmed from the disappearance of the $\mathrm{NH}_{2}$ signal and the detection of benzylidene $\mathrm{CH}$ signals around $8.30 \mathrm{ppm}$. Compound 19 displayed the $\mathrm{NH}$ of the ring at $\delta 13.54 \mathrm{ppm}$ and the $\mathrm{NH}_{2}$ protons at $5.61 \mathrm{ppm}$. The $\mathrm{C}=\mathrm{S}$ was found at $\delta 167.32 \mathrm{ppm}$. The structure of $\mathbf{2 0}$ missed the $\mathrm{NH}$ signal, while 21 illustrated the $\mathrm{NHNH}_{2}$ exchangeable signals at $\delta 7.81$ and $4.55 \mathrm{ppm}$. The benzoylated product 22 showed two NH signals at $\delta 9.64$ and $8.29 \mathrm{ppm}$. The hydrazones 23 and $\mathbf{2 4}$ displayed the $\mathrm{NH}$ signal at $\delta 11.79$ and $11.49 \mathrm{ppm}$, respectively, while the benzylidene $\mathrm{CH}$ was observed at $7.80 \mathrm{ppm}$ in the case of $\mathbf{2 3}$. The cyclic structures $\mathbf{2 5}$ and $\mathbf{2 6}$ did not show any NH signal; only $\mathrm{CH}$ signals appeared in the aromatic region at $9.48 \mathrm{ppm}$ in the case of 25 and two of the $\mathrm{CH}$ signals at 9.55 and $8.60 \mathrm{ppm}$ in the case of 26. The pyrazole ring structure 27 revealed two $\mathrm{CH}$ protons at $\delta 8.97$ and $6.17 \mathrm{ppm}$ for the pyrimidine and pyrazole $\mathrm{CH}$. The triazole-thione moiety construction in the case of $\mathbf{2 8}$ was identified from the detection of an $\mathrm{NH}$ at $\delta 14.62 \mathrm{ppm}$ and the thiocarbonyl carbon at $160.56 \mathrm{ppm}$. The ethers 29 and 30 showed the $\mathrm{CH}$ signal of the pyrimidine ring at $\delta 8.55$ and $8.52 \mathrm{ppm}$ in addition to the alkoxy group indicating signals. The NH signals appeared in the spectra of 31-34 at $\delta 8.34,8.13,5.09$, and 8.49 $\mathrm{ppm}$, respectively. The five-ring fused system 35 displayed the pyrimidine $\mathrm{CH}$ at $\delta 9.34 \mathrm{ppm}$, and the four phenyl protons appeared between $\delta 8.35$ and $7.57 \mathrm{ppm}$.<smiles>[R]Nc1ncnc2sc3c(c12)CCCC3</smiles>

31-34

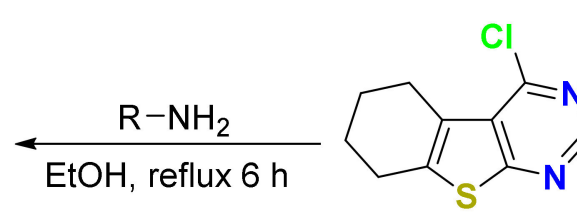

20

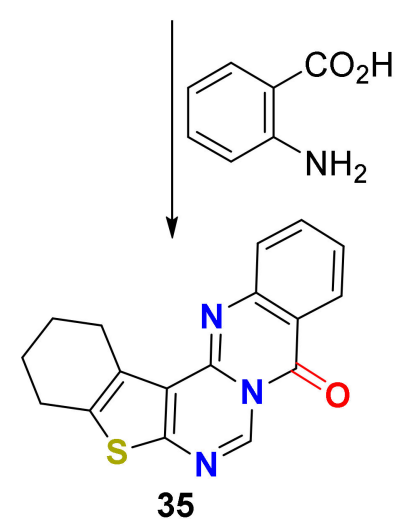

35

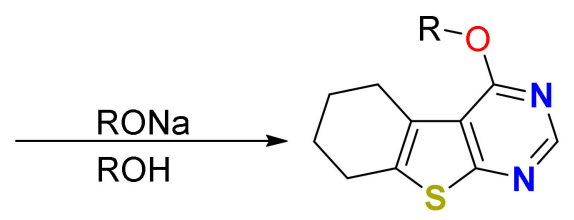

29,30

29, $\mathrm{R}=-\mathrm{CH}_{3}$ $30, \mathrm{R}=-\mathrm{CH}_{2} \mathrm{CH}_{3}$

$31, \mathrm{R}=p-\mathrm{CH}_{3} \mathrm{C}_{6} \mathrm{H}_{4}-$

32, $\mathrm{R}=\mathrm{C}_{6} \mathrm{H}_{5} \mathrm{CH}_{2-}$

33, $\mathrm{R}=p-\mathrm{HO}_{2} \mathrm{CC}_{6} \mathrm{H}_{4}-$

34, $\mathrm{R}=p-\mathrm{CH}_{3} \mathrm{COC}_{6} \mathrm{H}_{4}-$

Scheme 7. Synthesis of compounds 29-35 from the chloro derivative 20. 


\subsection{Biological Activity}

\subsubsection{Antitumor Activity Evaluation}

The synthesized compounds were tested for their antiproliferative activity against MCF-7 and HepG-2 cancer cell lines. Twelve compounds displayed a significant activity, which ranged from 23.2 to $95.9 \mu \mathrm{M}$. Compounds 4, 24, 29, 30, and 31 were the most active with an $\mathrm{IC}_{50}$ range from 23.2 to $49.9 \mu \mathrm{M}$. Compounds $\mathbf{5}, \mathbf{1 5}, \mathbf{2 1}, \mathbf{2 6}, \mathbf{2 7}, \mathbf{2 8}$, and 33 revealed a moderate activity in the range from 52.9 to $95.9 \mu \mathrm{M}$. The remaining derivatives showed a lower activity (Table 1 ).

Table 1. The in vitro inhibition \% found using $(100 \mu \mathrm{g} / \mathrm{mL})$ of a single dose and $\mathrm{IC}_{50}$ in $\mu \mathrm{g} / \mathrm{mL}$ and $\mu \mathrm{M}$ of the tested compounds on MCF-7 and HepG-2 cell lines.

\begin{tabular}{|c|c|c|c|c|c|c|}
\hline \multirow{2}{*}{ Entry } & \multicolumn{2}{|c|}{ MCF-7 } & \multicolumn{4}{|c|}{ HepG-2 } \\
\hline & Inhibition \% & $\begin{array}{c}\mathrm{IC}_{50} \\
\mu \mathrm{g} / \mathrm{mL}\end{array}$ & $\begin{array}{l}\mathrm{IC}_{50} \\
\mu \mathrm{M}\end{array}$ & Inhibition \% & $\begin{array}{c}\mathrm{IC}_{50} \\
\mu \mathrm{g} / \mathrm{mL}\end{array}$ & $\begin{array}{l}\mathrm{IC}_{50} \\
\mu \mathrm{M}\end{array}$ \\
\hline 2 & 27.12551 & ND & ND & 42.85714 & ND & ND \\
\hline 3 & 46.93572 & ND & ND & 43.42105 & ND & ND \\
\hline 4 & 80.625 & 7 & 23.2 & 78.63636 & 11.7 & 38.8 \\
\hline 5 & 75.91912 & 19.3 & 52.9 & 76.41221 & 19.3 & 52.9 \\
\hline 6 & 38.56502 & ND & ND & 45.17544 & ND & ND \\
\hline 7 & 74.77941 & 48 & 131.3 & 73.58779 & 37 & 101.2 \\
\hline 8 & 49.0284 & ND & ND & 52.41228 & ND & ND \\
\hline 9 & 45.06726 & ND & ND & 81.79825 & 36.5 & 140.7 \\
\hline 10 & 67.70833 & ND & ND & 78.18182 & 26.5 & 89.4 \\
\hline 11 & 45.29148 & ND & ND & 72.98246 & 16.5 & 50.9 \\
\hline 12 & 38.93871 & ND & ND & 73.07018 & 31 & 87.5 \\
\hline 13 & 56.65172 & ND & ND & 66.22807 & 27.5 & 94.0 \\
\hline 14 & 61.13602 & 43 & 154.5 & 69.34211 & 33.6 & 120.7 \\
\hline 15 & 60.46338 & 22 & 53.2 & 73.24561 & 22 & 53.2 \\
\hline 16 & 66.66667 & ND & ND & 77.09091 & 25 & 68.2 \\
\hline 17 & 67.70833 & ND & ND & 79.09091 & 42 & 110.4 \\
\hline 19 & 68.41912 & ND & ND & 77.17557 & 38.5 & 334.42 \\
\hline 20 & 34.90284 & ND & ND & 34.21053 & ND & ND \\
\hline 21 & 60.38864 & 28 & 127.1 & 69.73684 & 13.6 & 61.7 \\
\hline 22 & 31.98381 & ND & ND & 30.61224 & ND & ND \\
\hline 23 & 1.00005 & ND & ND & 3.508772 & ND & ND \\
\hline 24 & 72.39583 & 13 & 40.3 & 78.63636 & 10 & 31.0 \\
\hline 25 & 38.7145 & ND & ND & 29.82456 & ND & ND \\
\hline 26 & 70.67708 & 16.4 & 71.2 & 77.27273 & 29 & 125.9 \\
\hline 27 & 79.0625 & 21.7 & 76.3 & 77.72727 & 32.6 & 114.6 \\
\hline 28 & 70.40359 & 15.5 & 59.1 & 47.36842 & ND & ND \\
\hline 29 & 80.20833 & 11 & 49.9 & 76.36364 & 14.5 & 65.8 \\
\hline 30 & 72.91667 & 7.4 & 31.6 & 78.72727 & 8.8 & 37.6 \\
\hline 31 & 76.04167 & 9.8 & 33.2 & 80.45455 & 17 & 57.5 \\
\hline 32 & 47.36842 & ND & ND & 51.83673 & ND & ND \\
\hline 33 & 71.875 & 31.2 & 95.9 & 81.36364 & 40 & 122.9 \\
\hline 34 & 57.8125 & ND & ND & 77.63636 & ND & ND \\
\hline
\end{tabular}

ND: Not determined. 


\subsubsection{Flow Cytometric Analysis}

To demonstrate the apoptotic mechanistic mode of action, the MCF-7 cell line was treated with compound $4\left(\mathrm{IC}_{50}=23.2 \mu \mathrm{M}, 48 \mathrm{~h}\right.$ incubation) compared to untreated cells as the control, which include flow cytometric analyses including an FITC/Annexin-V-FITC/PI differential apoptosis/necrosis assessment, DNA content-flow cytometry aided cell cycle analysis, and acridine orange quantitative autophagy assessment. All flow cytometric methodologies were performed according to the standard protocols, as previously described by Kattan et al., 2020 [30].

\section{FITC/Annexin-V-FITC/PI Differential Apoptosis/Necrosis Assessment}

Double-staining with annexin-FITC and propidium iodide (PI) on MCF-7 cells treated with compound $4\left(\mathrm{IC}_{50}=23.2 \mu \mathrm{M}\right)$, and nontreated cells served as the negative control for $48 \mathrm{~h}$ to investigate whether it has an induction of apoptosis and/or cell cycle progression. As displayed in Figure 2, results show that the treatment caused apoptosis in MCF-7 cells with a substantial cell viability reduction of $26.86 \%$. The percentage of cells sub-populating in early apoptosis (AV+/PI-) was 8.73 , which is 2.3 times more relative to the untreated regulation. In addition, the average late apoptotic sub-population $(\mathrm{AV}+\mathrm{PI}+)$ count was $18.13 \%$, which is 6.6 times higher than the untreated control. Moreover, the tested compound 4 induced an increase with 1.89 -fold (6.29\%, compared to $3.33 \%$ for control) in cell death via necrosis, as shown in Figure 2. The results proved that the tested compound 4 effectively induced apoptosis and necrosis in MCF-7 cells.
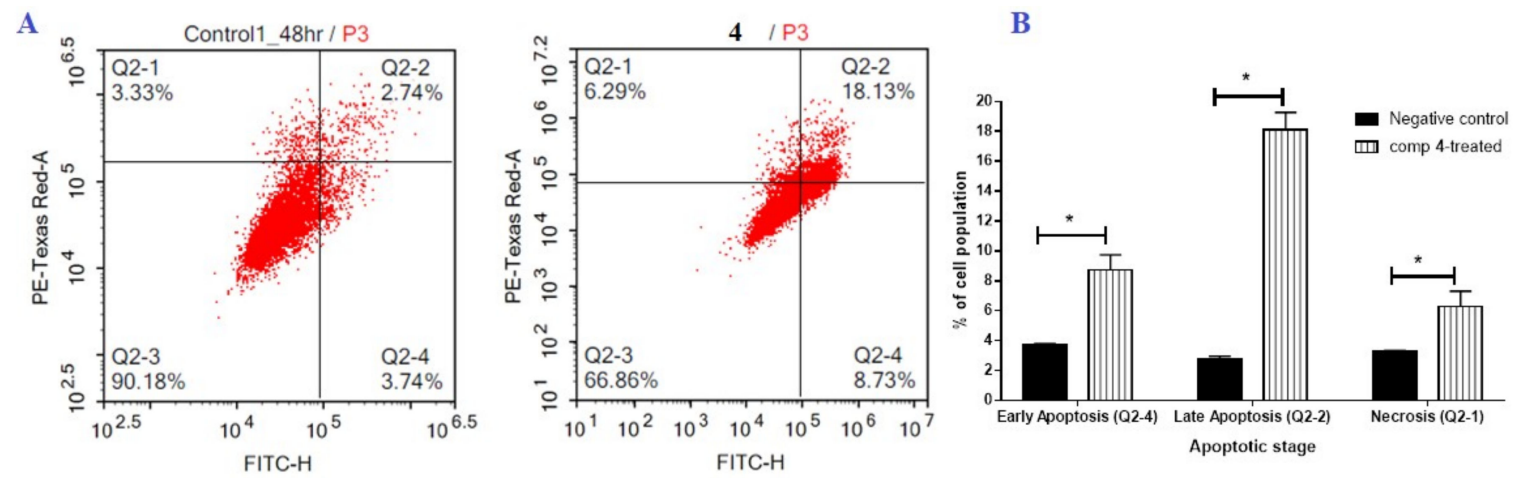

Figure 2. Induction of apoptosis in MCF-7 cells by compound $4(23.2 \mu \mathrm{M}, 48 \mathrm{~h})$. Cytograms showing annexin-V/propidium iodide stained MCF-7 cells: (A) MCF-7 cells nontreated with the negative control and treated with compound 4; (B) bar chart representation of the apoptosis analysis results, quadrant charts show Q2-1 (necrotic cells, AV-/PI+), Q2-2 (late apoptotic cells, AV+/PI+), Q2-3 (normal cells, AV-/PI-), Q2-4 (early apoptotic cells, AV+/PI-). ${ }^{*} p<0.05$ unpaired $t$-test compared to negative control.

DNA Content-Flow Cytometry Aided Cell Cycle Analysis

Cell cycle analysis is an important test that demonstrates the cell proliferation percentage during cell growth in every phase following cytotoxic compound treatment. Therefore, to analyze the cell cycle kinetics of MCF-7 cells treated with compound $4\left(\mathrm{IC}_{50}=23.2 \mu \mathrm{M}\right.$, 48h incubation), DNA flow cytometry was carried out to indicate phase interference with the cell cycle of the compound's. As shown in (Figure 3), results showed an induction an increase at G2/M-phase cell-cycle arrest with 1.48-fold (25.56\%, compared to $17.23 \%$ for control), and at S-phase cell-cycle arrest with 1.39 -fold $(23.38 \%$, compared to $16.76 \%$ for control) in cell population distribution, this may have resulted in genetic material degradation due to the apoptosis induction indicating compound 4 antiproliferative. 
A

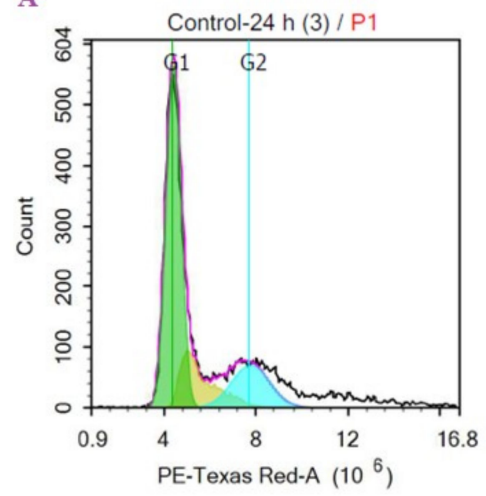

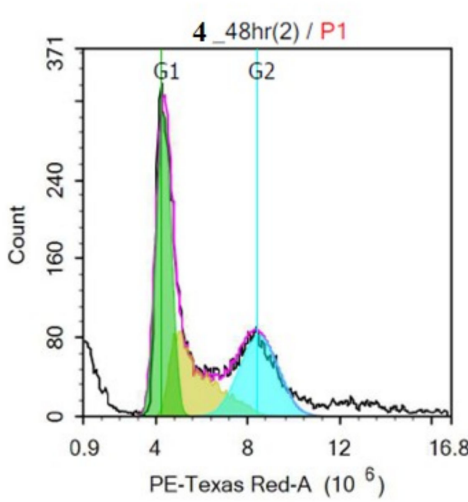

B

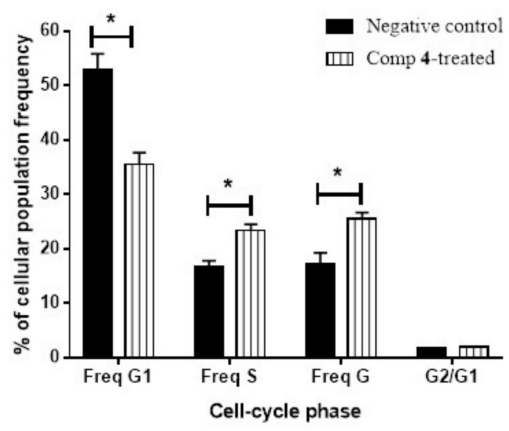

Figure 3. Cytogram reflecting the cell cycle distribution of MCF-7 cells (A): MCF-7 cells untreated and treated with compound $4(23.2 \mu \mathrm{M}, 48 \mathrm{~h})$; (B) bar chart representation of the percentage of cell population in different MCF-7 cell cycle phases. ${ }^{*} p<0.05$ unpaired $t$-test compared to negative control.

Acridine Orange Quantitative Autophagy Assessment

Herein, we further investigated the effect of compound $4\left(\mathrm{IC}_{50}=23.2 \mu \mathrm{M}\right)$ on the autophagy process within MCF-7 using the acridine orange lysosomal stain coupled with the flow cytometric analysis. The tested compound 4 did not induce any significant cell death by autophagy, it inhibited autophagic cell death (9.59\%, compared to $11.24 \%$ for control) and this proves the antiproliferative activity of compound 4 through apoptosis and necrosis as a dual activity (Figure 4).

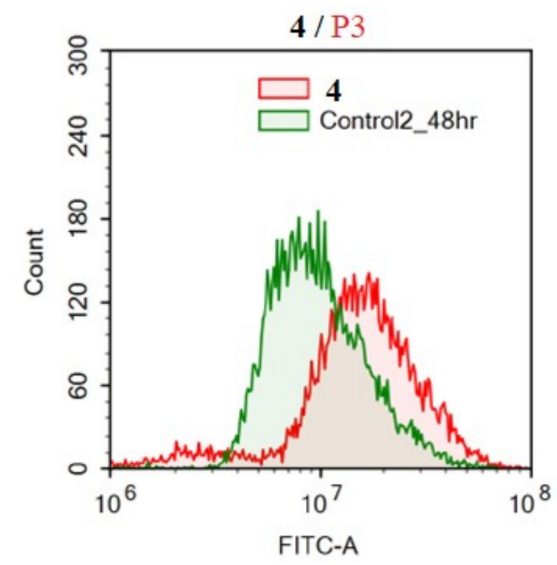

\begin{tabular}{llllll} 
\# & Sample & Gate & Count & $\%$ P3 & Mean X \\
\hline 1 & 4 & P3 & 9,593 & $100.00 \%$ & $18,266,894$ \\
2 & Control2_48h & P3* $^{*}$ & 11,240 & $100.00 \%$ & $11,377,536$
\end{tabular}

Figure 4. Autophagic cell death assessment in MCF-7 treated with compound $4\left(\mathrm{IC}_{50}=23.2 \mu \mathrm{M}\right)$ using the acridine orange lysosomal stain coupled with the flow cytometric analysis. The green curve for the negative control (untreated), and the red one for the compound 4-treated cells.

\subsubsection{In Silico Molecular Docking Studies}

A molecular docking study was made to investigate the binding interactions of hit 4 towards three proteins as JAK2 inhibitors; 3ZMM, 4C62, and 5AEP whose crystal structures complexed with their co-crystallized ligands were easily accessible from the Protein Data Bank. The co-crystallized ligands of the studied proteins form hydrogen bonds with Leu 932 as the key amino acid for interaction.

As seen in (Table 2) with 3D images, compound 4 was docked inside the protein active site of the studied proteins and formed one hydrogen bond with bond length $\left(\mathrm{A}^{\circ}\right)$ through the carbonyl group oxygen as a hydrogen bond acceptor with the key amino acid Leu 932 as their co-crystallized ligand 
with binding energy $-14.32,-13.39$, and $-11.38 \mathrm{Kcal} / \mathrm{mol}$, respectively. Additionally, compound 4 formed lipophilic interactions with the nonpolar amino acids (Leu 155, Val 24, Ile 140, Leu 90, and Leu 141) inside the receptor pocket. Different models obtained from the docking studies indicated that the designed target $\mathbf{4}$ showed promising binding activity as JAK2 inhibitors, and this may be the proposed mode of action for the anti-breast cancer activity.

Table 2. Analysis of ligand-receptor interactions with binding energies of docked compound 4 inside three proteins $3 \mathrm{ZMM}, 4 \mathrm{C} 62$, and 5AEP as Jak2 inhibitors.

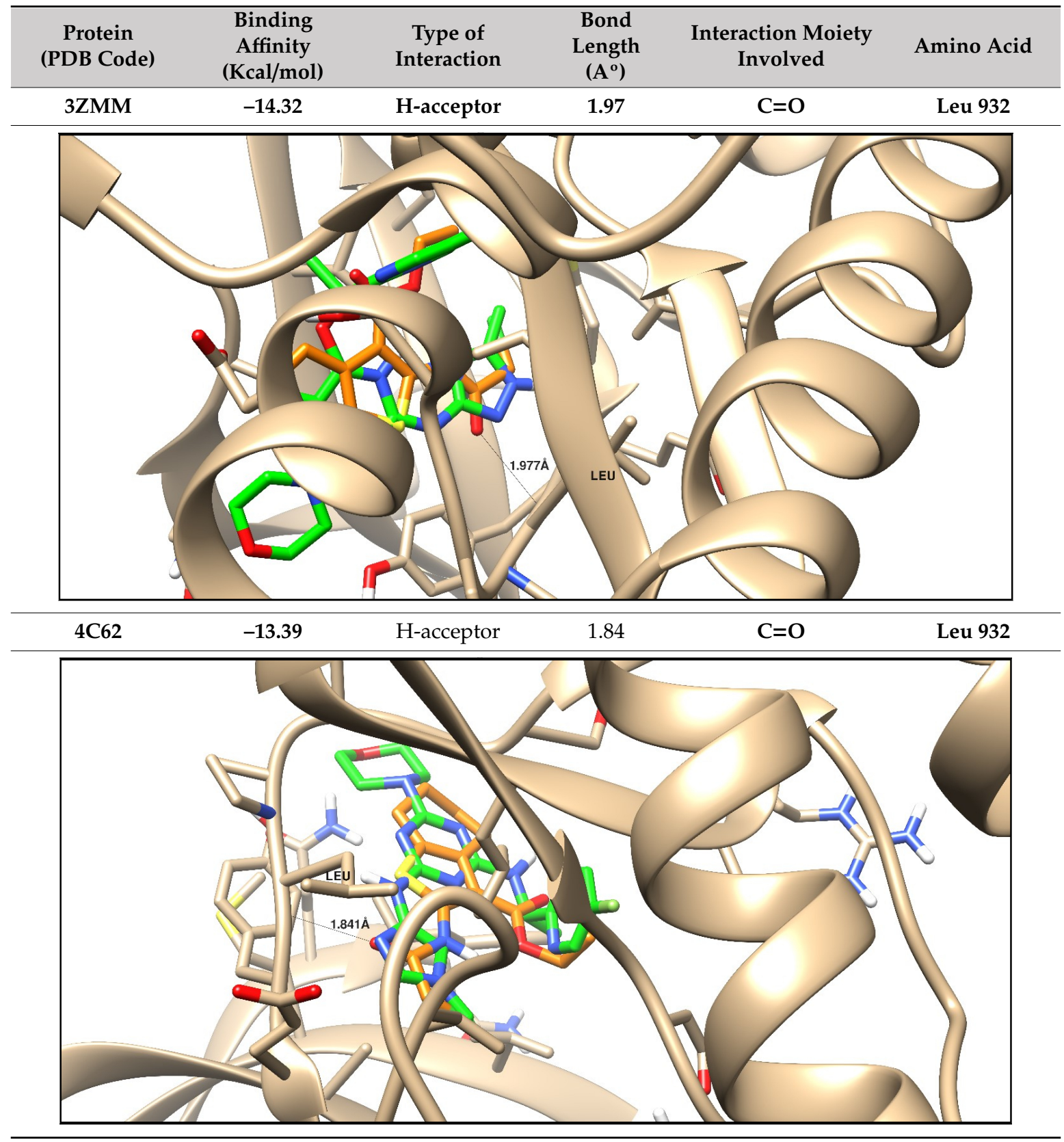


Table 2. Cont.

\begin{tabular}{cccccc}
\hline $\begin{array}{c}\text { Protein } \\
\text { (PDB Code) }\end{array}$ & $\begin{array}{c}\text { Binding } \\
\text { Affinity } \\
\text { (Kcal/mol) }\end{array}$ & $\begin{array}{c}\text { Type of } \\
\text { Interaction }\end{array}$ & $\begin{array}{c}\text { Bond } \\
\text { Length } \\
\left(\mathrm{A}^{\circ}\right)\end{array}$ & $\begin{array}{c}\text { Interaction Moiety } \\
\text { Involved }\end{array}$ & Amino Acid \\
\hline $5 \mathrm{AEP}$ & $-\mathbf{1 1 . 3 8}$ & H-acceptor & 1.67 & $\mathrm{C}=\mathrm{O}$ & Leu 932 \\
\hline & & & & &
\end{tabular}

Superimposed compound 4 (orange), and the co-crystalized ligand (green) of the three studied 3ZMM, 4C62, and 5AEP proteins.

\subsubsection{Bioinformatics Study}

Compounds with high binding affinity through ligand-receptor interactions and binding energy towards the investigated target (Jak2/STAT3) were subjected to bioinformatics study to predict the ADME pharmacokinetics properties. Drugs consistent with Lipinski's "five rule" (Ro5) are considered prospective in future [31-34]. For drug absorption through the intestine, TPSA surface topological polar area values should be 140 , and the barrier to blood brain should be as low as $90 \AA^{2}[30,31]$ The investigated compounds had good well-permeability and absorption. As shown in (Table 3) and (Figure 5), compounds had 0-1 Hydrogen-bond donor and 3-4 Hydrogen-bond acceptors. In addition, the tested compounds had $\log P$ range from 2.82 to 4.80 , so they had strong toleration by cell membranes. For managing conformational changes and for oral bioavailability, the number of rotabile bond (nrotb) should be less than 10 [31,35,36]. All the investigated compounds had 1-5 nrotb. Regarding to drug-likeness scores, compounds with positive values should be considered like drugs; all the tested compounds showed $0.15-0.73$ (positive values), so they seem to be drug-like.

Table 3. In silico ADME pharmacokinetics properties.

\begin{tabular}{ccccccccccc}
\hline & \multicolumn{9}{c}{ Molinspiration 2018.10 } & \multicolumn{4}{c}{ MolSoft } \\
\cline { 2 - 11 } & $\begin{array}{c}\text { MWt } \\
\mathbf{( D )}\end{array}$ & $\begin{array}{c}\text { MV } \\
\left.\mathbf{( A}^{\mathbf{3}}\right)\end{array}$ & $\begin{array}{c}\text { PSA } \\
\left(\mathbf{A}^{\mathbf{2}}\right)\end{array}$ & Log $\boldsymbol{P}$ & nrotb & nviolations & HBA & HBD $\begin{array}{c}\text { Solubility } \\
\mathbf{( m g} / \mathbf{L})\end{array}$ & $\begin{array}{c}\text { Drug-Likeness } \\
\text { Score }\end{array}$ \\
\hline $\mathbf{4}$ & 301.79 & 254.18 & 55.40 & 2.82 & 5 & 0 & 4 & 1 & 187.99 & 0.48 \\
\hline $\mathbf{3 1}$ & 295.40 & 267.17 & 37.81 & 4.80 & 2 & 0 & 3 & 1 & 2.51 & 0.48 \\
\hline $\mathbf{2 4}$ & 322.43 & 290.43 & 50.17 & 4.33 & 3 & 0 & 4 & 1 & 2.13 & 0.73 \\
\hline $\mathbf{3 0}$ & 234.31 & 209.15 & 35.02 & 3.03 & 2 & 0 & 4 & 0 & 14.58 & 0.15 \\
\hline
\end{tabular}

"Mwt: Molecular Weight, MV: Molecular Volume, PAS: Polar Surface Area, Log P: Octanol-water partition coefficient, nrotb: number of rotatable bond, nviolations: number of violations, HBA: Hydrogen Bond Acceptor, HBD: Hydrogen Bond Donor" [37]. 


\section{Drug-likeness model score: 0.48}

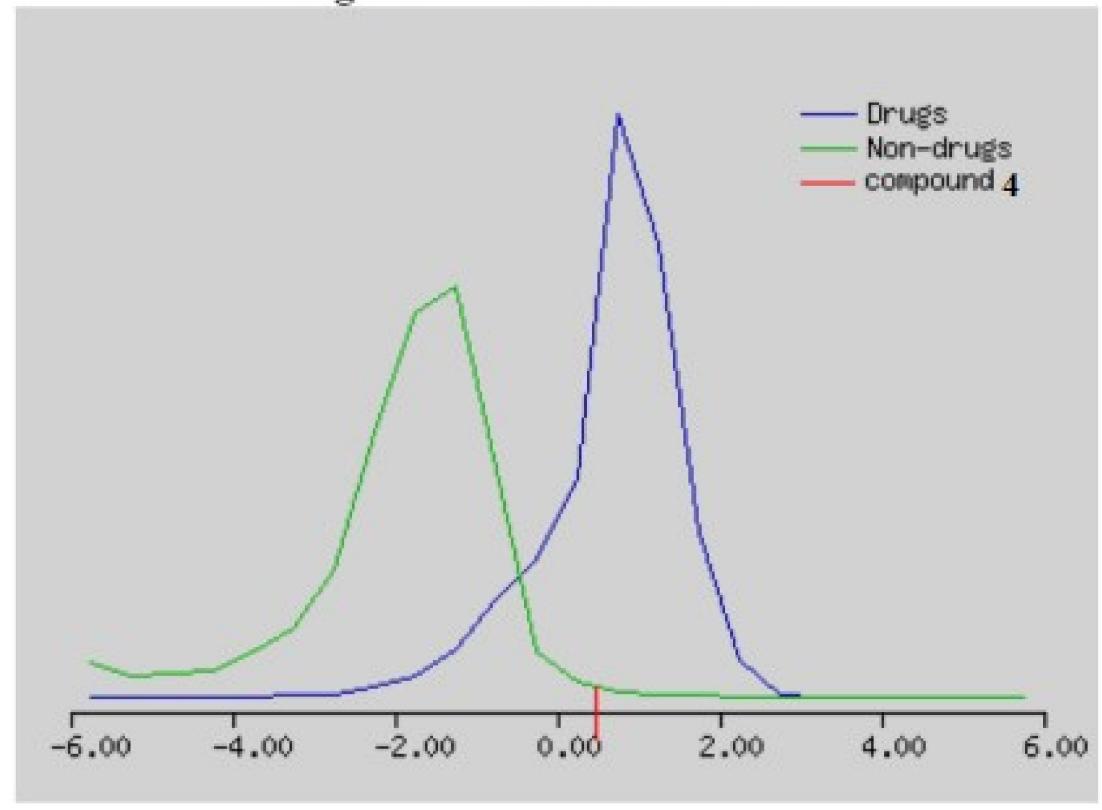

Figure 5. Plotting of Drug-likeness score of compound 4 using MolSoft. Non-drug like behavior (green-colored curve) and drug-like behavior (blue-colored curve). Compounds with zero or negative value should not seem to be as drug. Compound 4 has a value of 0.48 (positive value) as a drug-likeness score. It should be regarded as drug-like.

\subsubsection{In Vivo Study}

Solid Ehrlich Carcinoma (SEC) was treated daily with compound 4 to evaluate the in vivo effect on tumor cell growth, beginning on day 7 following inoculation of tumor cells. The compound had a total of seven doses, starting on day 7. At the end of the procedure, the weight of the solid tumor mass was measured. There was an increase in the solid tumor mass in SEC-bearing mice. During the experimental duration, an increase in the solid tumor weight of around $155 \mathrm{mg}$ was observed via the tumor development. The antitumor effect of compound 4 and 5-FU was elucidated; there was a significant decrease in the solid tumor mass by $54 \%(70 \mathrm{mg}$ ) and $67 \%$ (50 mg), respectively (Figure 6).

Accordingly, treatments with compound 4 significantly inhibited the percentage of tumor by $26.6 \%$ (tumor volume $=22 \mathrm{~mm}^{3}$ ) compared to the 5 -FU treatment $33.3 \%$ (tumor volume $=$ $20 \mathrm{~mm}^{3}$ ). The achieved results indicate that compound 4 has a promising therapeutic potential as an antitumor agent.

At the end of the experiment, animals from different groups were anesthetized, and blood samples were collected for the determination of liver enzymes ALT, AST levels, and CBC parameters, including $\mathrm{Hb}$ content, RBCs and WBCs counts. As seen in Table 4, in SEC-bearing mice, liver enzymes ALT and AST were found to be significantly increased to 84.65 and $97.64(\mathrm{U} / \mathrm{L})$, respectively, as compared to normal mice, this could be contributed to the hepatocellular damage following tumor inoculation. The treatment with compound 4, such as 5-FU, substantially reduced liver enzyme, where elevated transaminases ALT were restored to 64.28 , AST to 69.89 close to the normal values measured in normal mice (43.53 and 45.75 , respectively), indicating a noticeable improvement in the hepatocellular toxicity induced by SEC proliferation. 


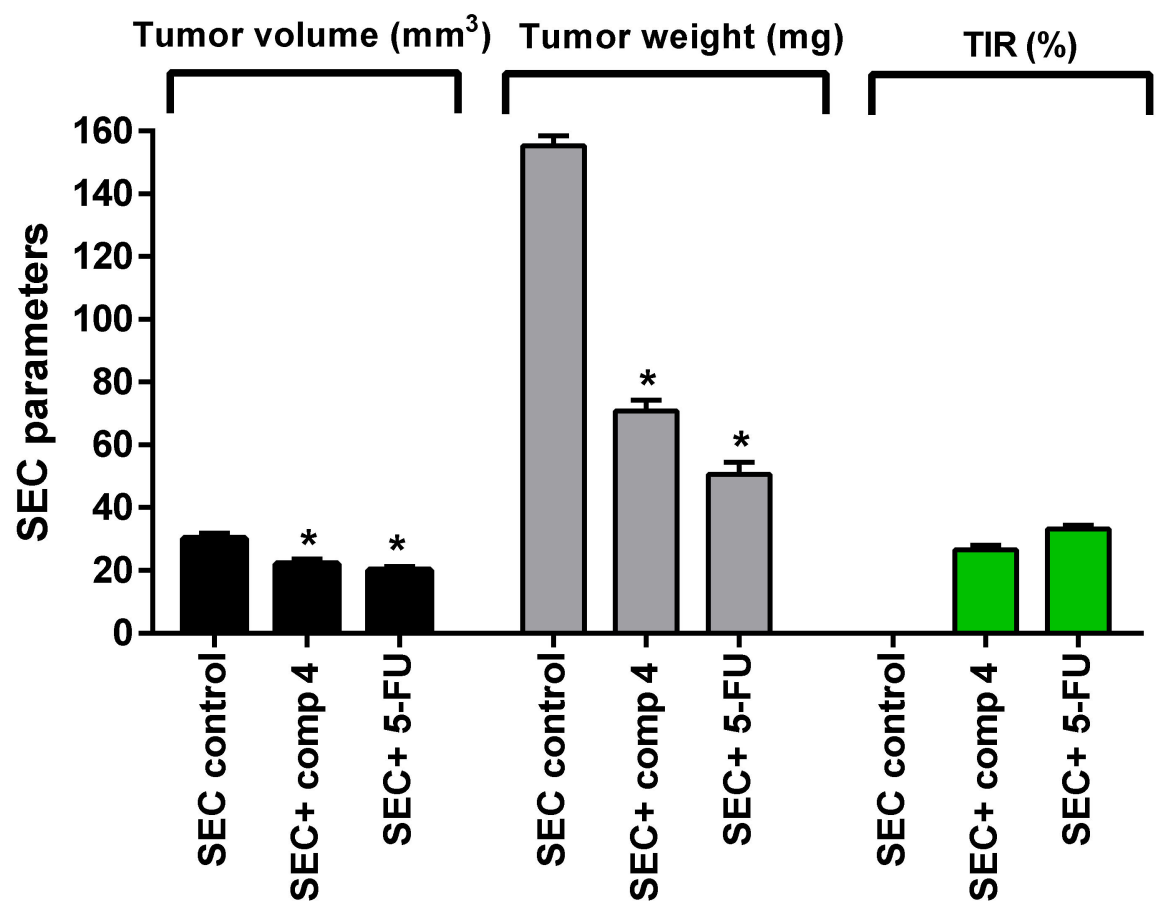

Figure 6. Solid Ehrlich Carcinoma (SEC)-bearing mice model. Different solid tumor mass, volume, tumor inhibition ratio (TIR \%) values are attributed to the antitumor activity. Mean \pm SEM values of mice in each group $(n=8)$. ${ }^{*}$ Mean \pm SEM values with a significant difference in tumor volume and tumor weight values compared to the SEC control using an unpaired $t$-test $(p \leq 0.05)$ using GraphPad prism.

Table 4. Evaluation of liver enzymes and hematological parameters in the studied groups.

\begin{tabular}{ccccc}
\hline Treatments & Positive Control & SEC Control & SEC + Comp 4 & SEC + 5-FU \\
\hline ALT $^{* \#}(\mathbf{I} / \mathrm{U})$ & $43.53 \pm 1.06$ & $84.65 \pm 2.1$ & $64.28 \pm 1.64$ & $51.31 \pm 1.41$ \\
\hline AST $^{* \#}(\mathbf{I} / \mathbf{U})$ & $45.75 \pm 0.97$ & $97.64 \pm 1.75$ & $59.89 \pm 1.85$ & $50.64 \pm 0.97$ \\
\hline $\mathbf{H b}^{* \#}(\mathrm{~g} / \mathbf{d L})$ & $7.9 \pm 0.86$ & $3.99 \pm 0.21$ & $5.99 \pm 0.49$ & $7.02 \pm 0.83$ \\
\hline RBCs count $^{* \#}(\times \mathbf{1 0} / \boldsymbol{\mu L})$ & $5.14 \pm 0.65$ & $3.28 \pm 0.73$ & $4.43 \pm 0.47$ & $4.98 \pm 021$ \\
\hline WBCs count $^{* *}(\times \mathbf{1 0} / \mu \mathrm{L})$ & $3.69 \pm 0.53$ & $4.89 \pm 0.49$ & $4.21 \pm 0.43$ & $3.98 \pm 0.32$ \\
\hline
\end{tabular}

${ }^{*}$ Mean \pm SEM values of mice in each group $(\mathrm{n}=8)$. ${ }^{\#}$ Values are significantly different $(p \leq 0.05)$, un-paired test using GraphPad prism.

Regarding hematological parameters in SEC-bearing mice, all CBC parameters were changed upon treatment with compound 4 where the $\mathrm{Hb}$ content and RBCs were significantly decreased to be $3.99(\mathrm{~g} / \mathrm{dL})$ and $3.28\left(10^{6} / \mu \mathrm{L}\right)$, respectively, while the WBCs count was significantly increased to be $4.89\left(10^{3} / \mu \mathrm{L}\right)$ compared to the normal control levels. Myelosuppression and anemia are the main issues of cancer chemotherapy. Anemia in a tumor-bearing mouse is primarily due to reductions in the RBC count and hemoglobin, which are either hemolytic or myelopathic [30]. CBC parameters for hemoglobin, $\mathrm{RBC}$, and WBC levels have been greatly improved by compound 4 treatments. CBC parameters improved to $5.99,4.43$, and 4.21, respectively, relative to normal control values 7.9, 5.14, and 3.69, hence demonstrating the ability of the tested compound to cure the change of the hematological parameters.

\section{Materials and Methods}

All general information about the equipment used in this text, biological activities assays (in vitro MTT assay, flow cytometric analysis, in silico molecular docking, bioinformatics study, and in vivo SEC model) of full protocols have been amended in the Supplementary Materials. 


\subsection{Synthesis}

Synthesis of (1): Sulpher $(0.02 \mathrm{~mol})$ was added to a mixture of ethyl cyanoacetate $(0.03 \mathrm{~mol})$ and cyclohexanone $(0.03 \mathrm{~mol})$ in $30 \mathrm{~mL}$ of ethanol followed by the addition of $\mathrm{Et}_{3} \mathrm{~N}(4.3 \mathrm{mmol})$, the mixture kept on stirring at an ambient temperature for $2 \mathrm{~h}$, then refluxed for further $2 \mathrm{~h}$. The reaction progress was monitored by TLC then, cooled, added to ice water, and kept overnight to complete the precipitation. The ppt was filtered, washed with water, dried, and recrystallized from ethanol to give yellow needle crystals.

\section{Ethyl 2-amino-4,5,6,7-tetrahydrobenzo[b]thiophene-3-carboxylate (1)}

Yield: $86 \%$, m.p. $110-11{ }^{\circ} \mathrm{C} ;{ }^{1} \mathrm{H}$ NMR $\left(400 \mathrm{MH}_{\mathrm{Z}}, \mathrm{DMSO}-d_{6}\right): \delta 7.15\left(\mathrm{~s}, 2 \mathrm{H}, \mathrm{D}_{2} \mathrm{O}\right.$ exchangeable, $\left.\mathrm{NH}_{2}\right), 4.15\left(\mathrm{q}, 2 \mathrm{H}, \mathrm{OCH}_{2} \mathrm{CH}_{3}\right), 2.42,2.61\left(2 \mathrm{~m}, 4 \mathrm{H}, 2 \mathrm{CH}_{2 \text { cyhex }}\right), 1.67-1.69\left(\mathrm{~m}, 4 \mathrm{H}, 2 \mathrm{CH}_{2 \text { cyhex }}\right), 1.25$ (t, $\left.3 \mathrm{H}, J 6.0 \mathrm{~Hz}, \mathrm{CH}_{3}\right) ;{ }^{13} \mathrm{C}$ NMR $\left(100 \mathrm{MH}_{\mathrm{Z}}\right.$, DMSO- $\left.d_{6}\right): \delta 165.53,163.33,131.80,115.97,103.25\left(4 \mathrm{C}_{\text {thiophene, }}\right.$ $\mathrm{C}=\mathrm{O}), 59.03\left(\mathrm{OCH}_{2}\right), 26.98,24.41,23.31,22.19\left(4 \mathrm{CH}_{2 \text { cyhex }}\right), 14.79\left(\mathrm{CH}_{3}\right) ; \mathrm{CHN}$ calcd. for: $\mathrm{C}_{11} \mathrm{H}_{15} \mathrm{NO}_{2} \mathrm{~S}$ [225.08]: C, 58.64; H, 6.71; N, 6.22; S, 14.23; found: C, 58.54; H, 6.69; N, 6.26; S, 14.12 .

Synthesis of (2) and (3): A mixture of amino-ester $1(2.2 \mathrm{mmol})$ and the appropriate isothiocyanate $\left(2.2 \mathrm{mmol}\right.$ ) and $\mathrm{Et}_{3} \mathrm{~N} 0.5 \mathrm{~mL}$ was refluxed in $30 \mathrm{~mL}$ of absolute ethanol for $3 \mathrm{~h}$ then left to cool. Acidified with concentrated $\mathrm{HCl}$, the formed ppt was collected by filtrations, washed with water, dried, and recrystallized from ethanol.

Ethyl 2-(3-phenylthioureido)-4,5,6,7-tetrahydrobenzo[b]thiophene-3-carboxylate (2)

Yield: 73\%, m.p. $173-174{ }^{\circ} \mathrm{C} ;{ }^{1} \mathrm{H}$ NMR $\left(400 \mathrm{MHz}\right.$, DMSO- $\left.d_{6}\right): \delta 11.78\left(\mathrm{~s}, 1 \mathrm{H}, \mathrm{D}_{2} \mathrm{O}\right.$ exchangeable, $\mathrm{NH}), 10.88\left(\mathrm{~s}, 1 \mathrm{H}, \mathrm{D}_{2} \mathrm{O}\right.$ exchangeable, NHPh), $7.49(\mathrm{~d}, 2 \mathrm{H}, \mathrm{Ph}), 7.41(\mathrm{t}, 2 \mathrm{H}, \mathrm{Ph}), 7.24(\mathrm{t}, 1 \mathrm{H}, \mathrm{Ph}), 4.23$ (q, 2H, OCH $\left.\mathrm{CH}_{3}\right), 2.72\left(\mathrm{~s}, 2 \mathrm{H}, \mathrm{CH}_{2 \text { cyhex }}\right), 2.60\left(\mathrm{~s}, 2 \mathrm{H}, 2 \mathrm{CH}_{2 \text { cyhex }}\right), 1.73\left(\mathrm{~s}, 4 \mathrm{H}, 2 \mathrm{CH}_{2 \text { cyhex }}\right), 1.28$ (t, $\left.3 \mathrm{H}, \mathrm{OCH}_{2} \mathrm{CH}_{3}\right) ;{ }^{13} \mathrm{C}$ NMR (100 MHz, DMSO-d $\left.)_{6}\right): \delta 176.36(\mathrm{C}=\mathrm{S}), 166.02(\mathrm{C}=\mathrm{O}), 150.00,138.69,130.49$, $129.35,126.34,126.14,124.78,112.42$, (4 $\left.\mathrm{C}_{\text {thiophene, }} 6 \mathrm{C}_{\text {phenyl }}\right), 60.72\left(\mathrm{OCH}_{2} \mathrm{CH}_{3}\right), 26.34,24.12,23.01$, 22.91, (4 $\left.\mathrm{CH}_{2 \text { cyhex }}\right), 14.52\left(\mathrm{CH}_{2} \mathrm{CH}_{3}\right) ; \mathrm{CHN}$ calcd. for: $\mathrm{C}_{18} \mathrm{H}_{20} \mathrm{~N}_{2} \mathrm{O}_{2} \mathrm{~S}_{2}$ [360.49]: $\mathrm{C}, 59.97 ; \mathrm{H}, 5.59 ; \mathrm{N}, 7.77$; S, 17.79; found: $\mathrm{C}, 59.95 ; \mathrm{H}, 5.56 ; \mathrm{N}, 7.73 ; \mathrm{S}, 17.77$.

\section{2-(Ethylamino)-5,6,7,8-tetrahydro-4H-benzo[4,5]thieno[2,3-d][1,3]thiazin-4-one (3)}

Yield: 70\%, m.p. $265-267^{\circ} \mathrm{C} ;{ }^{1} \mathrm{H}$ NMR $\left(400 \mathrm{MHz}\right.$, DMSO- $\left.d_{6}\right): \delta 13.43\left(\mathrm{~s}, 1 \mathrm{H}, \mathrm{D}_{2} \mathrm{O}\right.$ exchangeable, $\mathrm{NH}), 4.40$ (q, 2H, $\left.\mathrm{NHCH}_{2} \mathrm{CH}_{3}\right), 2.78,2.64$ (2brs, $\left.4 \mathrm{H}, 2 \mathrm{CH}_{2 \text { cyhex }}\right), 1.75\left(\mathrm{~m}, 4 \mathrm{H}, 2 \mathrm{CH}_{2 \text { cyhex }}\right), 1.20(\mathrm{t}, 3 \mathrm{H}$, $\left.\mathrm{CH}_{2} \mathrm{CH}_{3}\right) ;{ }^{13} \mathrm{C}$ NMR $\left(100 \mathrm{MHz}, \mathrm{DMSO}-d_{6}\right): \delta 173.56,156.64\left(\mathrm{C}=\mathrm{O}, \mathrm{C}_{\text {thiazin }}\right), 149.02,131.38,128.77$, 116.17 (4 $\left.\mathrm{C}_{\text {thiophene }}\right), 41.08\left(\mathrm{NHCH}_{2} \mathrm{CH}_{3}\right), 25.32,24.40,22.91,22.01\left(4 \mathrm{CH}_{2 \text { cyhex }}\right), 12.26\left(\mathrm{CH}_{2} \mathrm{CH}_{3}\right) ; \mathrm{CHN}$ calcd. for: $\mathrm{C}_{12} \mathrm{H}_{14} \mathrm{~N}_{2} \mathrm{OS}_{2}$ [266.38]: $\mathrm{C}, 54.11 ; \mathrm{H}, 5.30 ; \mathrm{N}, 10.52 ; \mathrm{S}, 24.07$; found: $\mathrm{C}, 54.22 ; \mathrm{H}, 5.32 ; \mathrm{N}, 10.50$; S, 24.04 .

Acylation with Chloroacetyl Chloride: A mixture of $1(4.5 \mathrm{mmol})$ and chloroacetyl chloride $(13.5 \mathrm{mmol})$ in $30 \mathrm{~mL}$ of methylene chloride containing $\mathrm{Et}_{3} \mathrm{~N}(0.5 \mathrm{~mL})$ was stirred for $3 \mathrm{~h}$ in an ice bath. The formed solid product was collected by filtration, dried, and recrystallized from ethanol.

Ethyl 2-(2-chloroacetamido)-4,5,6,7-tetrahydrobenzo[b]thiophene-3-carboxylate (4)

Yield: 75\%, m.p. $110-112{ }^{\circ} \mathrm{C} ;{ }^{1} \mathrm{H}$ NMR $\left(400 \mathrm{MHz}, \mathrm{DMSO}-\mathrm{d}_{6}\right): \delta 11.66\left(\mathrm{~s}, 1 \mathrm{H}, \mathrm{D}_{2} \mathrm{O}\right.$ exchangeable, $\mathrm{NH}), 4.57\left(\mathrm{~s}, 2 \mathrm{H}, \mathrm{CH}_{2} \mathrm{Cl}\right), 4.32\left(\mathrm{q}, 2 \mathrm{H}, \mathrm{OCH}_{2} \mathrm{CH}_{3}\right), 2.71\left(\mathrm{~s}, 4 \mathrm{H}, 2 \mathrm{CH}_{2 \text { cyhex }}\right), 2.61$ (s, 2H, $\left.2 \mathrm{CH}_{2 \text { cyhex }}\right)$, $1.73\left(\mathrm{~s}, 4 \mathrm{H}, 2 \mathrm{CH}_{2 \text { cyhex }}\right), 1.32\left(\mathrm{t}, 3 \mathrm{H}, \mathrm{CH}_{2} \mathrm{CH}_{3}\right) ;{ }^{13} \mathrm{C} \mathrm{NMR}\left(100 \mathrm{MHz}, \mathrm{DMSO}-d_{6}\right): \delta 165.45,164.23$ $\left(\mathrm{C}=\mathrm{O}_{\text {amide+ester }}\right), 145.55,131.18,127.30,112.78\left(4 \mathrm{C}_{\text {thiophene }}\right), 61.00\left(\mathrm{OCH}_{2} \mathrm{CH}_{3}\right), 43.01\left(\mathrm{CH}_{2} \mathrm{Cl}\right), 26.24$, 24.20, 22.89, $22.70\left(4 \mathrm{CH}_{2 \text { cyhex }}\right), 14.52\left(\mathrm{CH}_{2} \mathrm{CH}_{3}\right) ; \mathrm{CHN}$ calcd. for: $\mathrm{C}_{13} \mathrm{H}_{16} \mathrm{ClNO}_{3} \mathrm{~S}$ [301.79]: $\mathrm{C}, 51.74 ; \mathrm{H}$, $5.34 ; \mathrm{N}, 4.64 ; \mathrm{S}, 10.62$; found: $\mathrm{C}, 51.76 ; \mathrm{H}, 5.30 ; \mathrm{N}, 4.62 ; \mathrm{S}, 10.63$.

Synthesis of (5): A mixture of $4(1.6 \mathrm{mmol})$ and cyclohexylamine $(1.6 \mathrm{mmol})$ was refluxed in $30 \mathrm{~mL}$ of absolute ethanol for $3 \mathrm{~h}$ and cooled to room temperature. The formed solid was filtered, dried, and recrystallized from ethanol. 
Yield: $69 \%$, m.p. $140-141{ }^{\circ} \mathrm{C} ;{ }^{1} \mathrm{H}$ NMR (400 MHz, DMSO- $\left.d_{6}\right): \delta 1.29-4.69(\mathrm{~m}, 28 \mathrm{H}) ;{ }^{13} \mathrm{C}$ NMR $\left(100 \mathrm{MHz}, \mathrm{DMSO}-d_{6}\right): \delta 171.22,164.75\left(2 \mathrm{C}=\mathrm{O}_{\text {amide+ester }}\right), 146.07,131.04,126.12,111.77\left(4 \mathrm{C}_{\text {thiophene, }}\right)$, $60.46\left(\mathrm{OCH}_{2} \mathrm{CH}_{3}\right), 57.35,49.99,33.25,26.33,26.17,24.89,24.26,23.01,22.85\left(9 \mathrm{CH}_{2 \text { cyhex }}, \mathrm{CH}_{\text {cyhex }}\right), 14.67$ $\left(\mathrm{CH}_{2} \mathrm{CH}_{3}\right)$; $\mathrm{CHN}$ calcd. for: $\mathrm{C}_{19} \mathrm{H}_{28} \mathrm{~N}_{2} \mathrm{O}_{3} \mathrm{~S}$ [364.50]: $\mathrm{C}, 62.61 ; \mathrm{H}, 7.74 ; \mathrm{N}, 7.69 ; \mathrm{S}, 8.80$; found: $\mathrm{C}, 62.60$; $\mathrm{H}, 7.70 ; \mathrm{N}, 7.66 ; \mathrm{S}, 8.81$.

Synthesis of (6): A mixture of $1(3.8 \mathrm{mmol})$, benzoyl chloride $(4.3 \mathrm{mmol})$, and few drops of triethylamine was refluxed for $4 \mathrm{~h}$ in dry benzene. The reaction mixture was concentrated and cooled at room temperature. The formed ppt was collected and recrystallized from ethanol to obtain yellow crystals.

\section{Ethyl 2-benzamido-4,5,6,7-tetrahydrobenzo[b]thiophene-3-carboxylate (6)}

Yield: $8 \%$, m.p. $170-172{ }^{\circ} \mathrm{C} ;{ }^{1} \mathrm{H}$ NMR (400 MHz, DMSO- $\left.d_{6}\right): \delta 12.03\left(\mathrm{~s}, 1 \mathrm{H}, \mathrm{D}_{2} \mathrm{O}\right.$ exchangeable, $\mathrm{NH}), 7.64-7.93\left(\mathrm{~m}, 5 \mathrm{H}\right.$, phenyl), $4.35\left(\mathrm{q}, 2 \mathrm{H}, \mathrm{OCH}_{2} \mathrm{CH}_{3}\right), 2.66,2.76\left(2 \mathrm{brs}, 4 \mathrm{H}, 2 \mathrm{CH}_{2 \text { cyhex }}\right), 1.76$ (brs, $4 \mathrm{H}$, $\left.2 \mathrm{CH}_{2 \text { cyhex }}\right), 1.35\left(\mathrm{t}, 3 \mathrm{H}, \mathrm{CH}_{2} \mathrm{CH}_{3}\right) ;{ }^{13} \mathrm{C} \mathrm{NMR}\left(100 \mathrm{MHz}, \mathrm{DMSO}-d_{6}\right): \delta 166.23,163.06\left(2 \mathrm{C}=\mathrm{O}_{\text {ester+amide }}\right)$, 147.01, 133.21, 132.54, 131.21, 129.64, 127.46, 127.03 (4 $\left.\mathrm{C}_{\text {thiophene, }} 6 \mathrm{C}_{\text {phenyl }}\right), 61.04\left(\mathrm{OCH}_{2} \mathrm{CH}_{3}\right), 26.29$, 24.27, 22.97, $22.75\left(4 \mathrm{CH}_{2 \text { cyhex }}\right), 14.52\left(\mathrm{OCH}_{2} \mathrm{CH}_{3}\right)$; $\mathrm{CHN}$ calcd. for: $\mathrm{C}_{18} \mathrm{H}_{19} \mathrm{NO}_{3} \mathrm{~S}$ [329.41]: $\mathrm{C}, 65.63 ; \mathrm{H}$, $5.81 ; \mathrm{N}, 4.25 ; \mathrm{S}, 9.73$; found: $\mathrm{C}, 65.60 ; \mathrm{H}, 5.84 ; \mathrm{N}, 4.15 ; \mathrm{S}, 9.5$.

Synthesis of (7): A mixture of compound $1(2.2 \mathrm{mmol})$ and benzenesulfonyl chloride $(2.2 \mathrm{mmol})$ was refluxed in $30 \mathrm{~mL}$ of absolute ethanol for $4 \mathrm{~h}$ then cooled to room temperature. The ppt was collected by filtration, washed with ethanol, and recrystallized from ethanol.

Ethyl 2-(phenylsulfonamido)-4,5,6,7-tetrahydrobenzo[b]thiophene-3-carboxylate (7)

Yield: 73\%, m.p. $107-108^{\circ} \mathrm{C} ;{ }^{1} \mathrm{H}$ NMR (400 MHz, DMSO- $\left.d_{6}\right): \delta 10.36(\mathrm{~s}, 1 \mathrm{H}, \mathrm{NH}), 7.81$ (d, 2H, Ph), $7.68(\mathrm{t}, 1 \mathrm{H}, \mathrm{Ph}), 7.60(\mathrm{t}, 2 \mathrm{H}, \mathrm{Ph}), 4.14\left(\mathrm{q}, 2 \mathrm{H}, \mathrm{OCH}_{2} \mathrm{CH}_{3}\right), 2.56-2.59\left(\mathrm{~m}, 4 \mathrm{H}, 2 \mathrm{CH}_{2 \text { cyhex }}\right), 1.68-1.69(\mathrm{~m}$, $\left.4 \mathrm{H}, 2 \mathrm{CH}_{2 \text { cyhex }}\right), 1.21\left(\mathrm{t}, 3 \mathrm{H}, \mathrm{OCH}_{2} \mathrm{CH}_{3}\right) ;{ }^{13} \mathrm{C} \mathrm{NMR}\left(100 \mathrm{MHz}, \mathrm{DMSO}-d_{6}\right): \delta 163.84\left(\mathrm{C}=\mathrm{O}_{\text {ester }}\right), 142.70$, $139.46,133.87,132.91,130.13,129.82,127.29,120.47\left(4 \mathrm{C}_{\text {thiophene+ }}, 6 \mathrm{C}_{\text {phenyl }}\right), 60.76\left(\mathrm{OCH}_{2} \mathrm{CH}_{3}\right), 25.92$, 24.47, 22.81, $22.42\left(4 \mathrm{CH}_{2 \text { cyhex }}\right), 14.38\left(\mathrm{OCH}_{2} \mathrm{CH}_{3}\right) ; \mathrm{CHN}$ calcd. for: $\mathrm{C}_{17} \mathrm{H}_{19} \mathrm{NO}_{4} \mathrm{~S}_{2}$ [365.46]: $\mathrm{C}, 55.87 ; \mathrm{H}$, $5.24 ; \mathrm{N}, 3.83$; S, 17.54; found: $\mathrm{C}, 55.88 ; \mathrm{H}, 5.26 ; \mathrm{N}, 3.80 ; \mathrm{S}, 17.56$.

Synthesis of (8): A mixture of $\mathbf{1}(4.5 \mathrm{mmol})$ and formamide $(0.44 \mathrm{~mol})$ was refluxed for $3 \mathrm{~h}$. Cooled, poured onto cold water, and left at room temperature overnight, the formed ppt was filtered off and recrystallized from methanol to give brown needle crystals.

4,5,6,7,8-Tetrahydrobenzo[4,5]thieno[2,3-d]pyrimidin-4(3H)-one (8)

Yield: $90 \%$, m.p. $250-251{ }^{\circ} \mathrm{C} ;{ }^{1} \mathrm{H}$ NMR (400 MHz, DMSO- $\left.d_{6}\right): \delta 12.20\left(\mathrm{~s}, 1 \mathrm{H}, \mathrm{D}_{2} \mathrm{O}\right.$ exchangeable, $\mathrm{NH}), 7.96$ (s, $\left.1 \mathrm{H}, \mathrm{CH}_{\text {pyrimid. }}\right), 2.72,2.86$ (2brs, $\left.4 \mathrm{H}, 2 \mathrm{CH}_{2 \text { cyhex }}\right), 1.74-1.80\left(\mathrm{~m}, 4 \mathrm{H}, 2 \mathrm{CH}_{2 \text { cyhex }}\right) ;{ }^{13} \mathrm{C} \mathrm{NMR}$ $\left(100 \mathrm{MHz}, \mathrm{DMSO}-d_{6}\right): \delta 162.89,158.1,145.2,132.57,131.3,123.2\left(4 \mathrm{C}_{\text {thiophene, }} 2 \mathrm{C}_{\text {pyrimidone }}\right), 25.79,24.90$, 22.94, 22.24 ( $4 \mathrm{CH}_{2 \text { cyhex }}$ ); $\mathrm{CHN}$ calcd. for: $\mathrm{C}_{10} \mathrm{H}_{10} \mathrm{~N}_{2} \mathrm{OS}$ [206.26]: $\mathrm{C}, 58.23 ; \mathrm{H}, 4.89 ; \mathrm{N}, 13.58 ; \mathrm{S}, 15.54$; found: $\mathrm{C}, 58.25 ; \mathrm{H}, 4.90 ; \mathrm{N}, 13.57 ; \mathrm{S}, 15.50$.

Michael Addition Procedures: A mixture of pyrimidinone $8(3.4 \mathrm{mmol})$, acrylonitrile $(4.6 \mathrm{mmol})$, and $\mathrm{Et}_{3} \mathrm{~N}(0.3 \mathrm{~mL})$ in $25 \mathrm{~mL}$ of ethanol was refluxed for $6 \mathrm{~h}$, left to cool, a solid product formed, filtered off, and recrystallized from ethanol to give colorless crystals.

\section{3-(4-Oxo-5,6,7,8-tetrahydrobenzo[4,5]thieno[2,3-d]pyrimidin-3(4H)-yl)propanenitrile (9)}

Yield: $73 \%$, m.p. $173-175^{\circ} \mathrm{C} ;{ }^{1} \mathrm{H}$ NMR $\left(400 \mathrm{MHz}\right.$, DMSO- $\left.d_{6}\right): \delta 8.37\left(\mathrm{~s}, 1 \mathrm{H}, \mathrm{CH}_{\text {pyrimidine }}\right), 4.23-4.25$ (m, 2H, $\mathrm{NCH}_{2}$ ), 3.02-3.04 (m, 2H, $\mathrm{CH}_{2} \mathrm{CH}_{2} \mathrm{CN}$ ), 2.89 (brs, 2H, $\left.\mathrm{CH}_{2 \text { cyhex }}\right), 2.75$ (brs, $2 \mathrm{H}, \mathrm{CH}_{2 \text { cyhex }}$ ), 1.79 (brs, $\left.4 \mathrm{H}, 2 \mathrm{CH}_{2 \text { cyhex }}\right) ;{ }^{13} \mathrm{C}$ NMR (100 MHz, DMSO- $\left.d_{6}\right): \delta 162.10(\mathrm{C}=\mathrm{O}$ pyrimidone $), 157.20,147.55$, $133.79,131.35,122.15,118.56\left(6 \mathrm{C}_{(1 \text { pyrimidone+4thiophene+CN) }}\right), 41.84\left(\mathrm{NCH}_{2}\right), 25.77,25.02,22.85,22.20$ (4 $\left.\mathrm{CH}_{2 \text { cyhex }}\right), 17.49\left(\mathrm{CH}_{2} \mathrm{CN}\right)$; $\mathrm{CHN}$ calcd. for: $\mathrm{C}_{13} \mathrm{H}_{13} \mathrm{~N}_{3} \mathrm{OS}$ [259.33]: $\mathrm{C}, 60.21 ; \mathrm{H}, 5.05 ; \mathrm{N}, 16.20 ; \mathrm{S}, 12.36$; found: $\mathrm{C}, 60.23 ; \mathrm{H}, 5.10 ; \mathrm{N}, 16.23 ; \mathrm{S}, 12.34$.

General Procedure for Preparation of Compounds (10-13): To a mixture of pyrimidinone 8 $(3.0 \mathrm{mmol})$, the appropriate alkyl halide $(3.3 \mathrm{mmol})$ and anhydrous potassium carbonate $(3.6 \mathrm{mmol})$ 
was refluxed in $20 \mathrm{~mL}$ of DMF for $4 \mathrm{~h}$. Then cooled, poured in cold water, the ppt was filtered off and recrystallized from ethanol to afford the alkylated products 10-13.

3-Benzyl-5,6,7,8-tetrahydrobenzo[4,5]thieno[2,3-d]pyrimidin-4(3H)-one (10)

Yield: $73 \%$, m.p. $190{ }^{\circ} \mathrm{C} ;{ }^{1} \mathrm{H}$ NMR (400 MHz, DMSO- $\left.d_{6}\right): \delta 8.47\left(\mathrm{~s}, 1 \mathrm{H}, \mathrm{CH}_{\text {pyrimidine }}\right), 7.34$ (s, 5 $\left.\mathrm{H}_{\text {phenyl }}\right), 5.18\left(\mathrm{~s}, 2 \mathrm{H}, \mathrm{NCH}_{2}\right), 2.90-2.89\left(\mathrm{~m}, 2 \mathrm{H}, \mathrm{CH}_{2 \text { cyhex }}\right), 2.75-2.74\left(\mathrm{~m}, 2 \mathrm{H}, \mathrm{CH}_{2 \text { cyhex }}\right), 1.81-1.75(\mathrm{~m}, 4 \mathrm{H}$, $\left.2 \mathrm{CH}_{2 \text { cyhex }}\right) ;{ }^{13} \mathrm{C}$ NMR (100 MHz, DMSO- $\left.d_{6}\right): \delta 162.01$ ( $\left.\mathrm{C}=\mathrm{O}_{\text {pyrimidone }}\right), 157.32,147.92,137.36,133.62$, $131.38,129.07,128.09,122.42\left(11 \mathrm{C}_{(1 \text { pyrimidone+4thiophene+6phenyl })}\right), 48.83\left(\mathrm{NCH}_{2}\right), 25.81,25.01,22.84,22.21$ (4 $\mathrm{CH}_{2 \text { cyhex }}$ ); $\mathrm{CHN}$ calcd. for: $\mathrm{C}_{17} \mathrm{H}_{16} \mathrm{~N}_{2} \mathrm{OS}$ [296.39]: $\mathrm{C}, 68.89 ; \mathrm{H}, 5.44 ; \mathrm{N}, 9.45 ; \mathrm{S}, 10.82$; found: $\mathrm{C}, 68.88$; $\mathrm{H}, 5.46 ; \mathrm{N}, 9.43 ; \mathrm{S}, 10.80$.

3-(2-Oxo-2-phenylethyl)-5,6,7,8-tetrahydrobenzo[4,5]thieno[2,3-d]pyrimidin-4(3H)-one (11)

Yield: $85 \%$ pale brown crystals, m.p. $190-192{ }^{\circ} \mathrm{C} ;{ }^{1} \mathrm{H}$ NMR $\left(400 \mathrm{MHz}, \mathrm{DMSO}-d_{6}\right): \delta 8.29(\mathrm{~s}, 1 \mathrm{H}$, $\left.\mathrm{CH}_{\text {pyrimidine }}\right), 8.10\left(\mathrm{~d}, 2 \mathrm{H}_{\text {phenyl }}\right), 7.75\left(\mathrm{t}, 2 \mathrm{H}_{\text {phenyl }}\right), 7.62\left(\mathrm{t}, 1 \mathrm{H}_{\text {phenyl }}\right), 5.60\left(\mathrm{~s}, 2 \mathrm{H}, \mathrm{NCH}_{2}\right), 2.86(\mathrm{brs}, 2 \mathrm{H}$, $\left.\mathrm{CH}_{2 \text { cyhex }}\right), 2.78$ (brs, $\left.2 \mathrm{H}, \mathrm{CH}_{2 \text { cyhex }}\right), 1.78-1.83\left(\mathrm{~m}, 4 \mathrm{H}, 2 \mathrm{CH}_{2 \text { cyhex }}\right) ;{ }^{13} \mathrm{C}$ NMR (100 MHz, DMSO- $\left.d_{6}\right): \delta$ $193.25\left(C=\mathrm{O}_{\text {phenacyl }}\right), 162.22\left(\mathrm{C}=\mathrm{O}_{\text {pyrimidine }}\right), 157.26,148.28,134.91,134.59,133.67,131.33,129.47,128.50$,

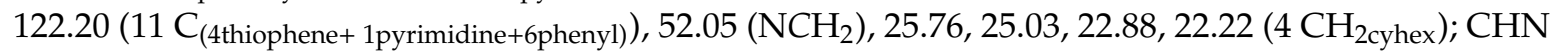
calcd. for: $\mathrm{C}_{18} \mathrm{H}_{16} \mathrm{~N}_{2} \mathrm{O}_{2} \mathrm{~S}$ [324.40]: $\mathrm{C}, 66.64 ; \mathrm{H}, 4.97 ; \mathrm{N}, 8.64 ; \mathrm{S}, 9.88$; found: $\mathrm{C}, 66.60 ; \mathrm{H}, 4.95 ; \mathrm{N}, 8.66$; S, 9.90 .

\section{3-(2-(4-methoxyphenyl)-2-oxoethyl)-5,6,7,8-tetrahydrobenzo[4,5]thieno[2,3-d]pyrimidin-4(3H)-one (12)}

Yield: $90 \%$ as yellow crystals, m.p. $145-146{ }^{\circ} \mathrm{C} ;{ }^{1} \mathrm{H}$ NMR $\left(400 \mathrm{MHz}, \mathrm{DMSO}-d_{6}\right): \delta 8.27(\mathrm{~s}, 1 \mathrm{H}$, $\left.\mathrm{CH}_{\text {pyrimidine }}\right), 8.08\left(\mathrm{~d}, 2 \mathrm{H}_{\text {phenyl }}\right), 7.14\left(\mathrm{~d}, 2 \mathrm{H}_{\text {phenyl }}\right), 5.53\left(\mathrm{~s}, 2 \mathrm{H}, \mathrm{NCH}_{2}\right), 3.90\left(\mathrm{~s}, 3 \mathrm{H}, \mathrm{OCH}_{3}\right), 2.86(\mathrm{~s}$, $\left.2 \mathrm{H}, \mathrm{CH}_{2 \text { cyhex }}\right), 2.78\left(\mathrm{~s}, 2 \mathrm{H}, \mathrm{CH}_{2 \text { cyhex }}\right), 1.77-1.81\left(\mathrm{~m}, 4 \mathrm{H}, 2 \mathrm{CH}_{2 \text { cyhex }}\right) ;{ }^{13} \mathrm{C}$ NMR (100 MHz, DMSO- $\left.d_{6}\right)$ : $\delta 191.48\left(\mathrm{C}=\mathrm{O}_{\text {phenacyl }}\right), 164.35\left(\mathrm{C}=\mathrm{O}_{\text {pyrimidine }}\right), 162.24,157.29,148.36,133.58,131.32,130.88,127.81$, 122.20, $114.72\left(11 \mathrm{C}_{\text {(4thiophene+ 1pyrimidine+6phenyl })}\right), 56.14\left(\mathrm{OCH}_{3}\right), 51.64\left(\mathrm{NCH}_{2}\right), 25.76,25.02,22.88,22.22$ (4 $\mathrm{CH}_{2 \text { cyhex }}$ ); $\mathrm{CHN}$ calcd. for: $\mathrm{C}_{19} \mathrm{H}_{18} \mathrm{~N}_{2} \mathrm{O}_{3} \mathrm{~S}$ [354.42]: $\mathrm{C}, 64.39 ; \mathrm{H}, 5.12 ; \mathrm{N}, 7.90 ; \mathrm{S}, 9.05$; found: $\mathrm{C}, 64.41$; $\mathrm{H}, 5.14 ; \mathrm{N}, 7.93 ; \mathrm{S}, 9.00$.

Ethyl 2-(4-oxo-5,6,7,8-tetrahydrobenzo[4,5]thieno[2,3-d]pyrimidin-3(4H)-yl)acetate (13)

Yield: $82 \%$ pale brown needles, m.p. $113-114{ }^{\circ} \mathrm{C} ;{ }^{1} \mathrm{H}$ NMR $\left(400 \mathrm{MHz}\right.$, DMSO- $\left.d_{6}\right): \delta 8.30(\mathrm{~s}, 1 \mathrm{H}$, $\left.\mathrm{CH}_{\text {pyrimdine }}\right), 4.79\left(\mathrm{~s}, 2 \mathrm{H}, \mathrm{NCH}_{2}\right), 4.18\left(\mathrm{q}, \mathrm{J}=8.0 \mathrm{~Hz}, 2 \mathrm{H}, \mathrm{OCH}_{2} \mathrm{CH}_{3}\right), 2.87$ (brs, $\left.2 \mathrm{H}, \mathrm{CH}_{2 \text { cyhex }}\right), 2.65$ (brs, $\left.2 \mathrm{H}, \mathrm{CH}_{2 \text { cyhex }}\right), 1.79\left(\mathrm{~m}, 4 \mathrm{H}, 2 \mathrm{CH}_{2 \text { cyhex }}\right), 1.23\left(\mathrm{t}, 3 \mathrm{H}, \mathrm{CH}_{3}\right) ;{ }^{13} \mathrm{C}$ NMR $\left(100 \mathrm{MHz}, \mathrm{DMSO}-d_{6}\right): \delta 168.29$ $\left(\mathrm{C}=\mathrm{O}_{\text {ester }}\right), 162.17$ ( $\left.\mathrm{C}=\mathrm{O}_{\text {pyrimidine }}\right), 157.21,147.95,133.85,131.29,122.08$ ( $\left.4 \mathrm{C}_{\text {thiophene, }}, 1 \mathrm{C}_{\text {pyrimidine }}\right), 61.71$ $\left(\mathrm{OCH}_{2} \mathrm{CH}_{3}\right), 47.25\left(\mathrm{NCH}_{2}\right), 25.72,25.00,22.85,22.19\left(4 \mathrm{CH}_{2 \text { cyhex }}\right), 14.45\left(\mathrm{CH}_{2} \mathrm{CH}_{3}\right) ; \mathrm{CHN}$ calcd. for: $\mathrm{C}_{14} \mathrm{H}_{16} \mathrm{~N}_{2} \mathrm{O}_{3} \mathrm{~S}$ [292.35]: C, 57.52; H, 5.52; N, 9.58; S, 10.97; found: $\mathrm{C}, 57.48 ; \mathrm{H}, 5.50 ; \mathrm{N}, 9.61 ; \mathrm{S}, 10.99$.

Synthesis of (14): A mixture of ester $13(3.0 \mathrm{mmol})$ and hydrazine hydrate $(6.0 \mathrm{mmol})$ in $30 \mathrm{~mL}$ of ethanol was refluxed for $3 \mathrm{~h}$, the reaction mixture was cooled, the solid product was filtered off, dried, and recrystallized from $\mathrm{EtOH} / \mathrm{DMF}$.

2-(4-Oxo-5,6,7,8-tetrahydrobenzo[4,5]thieno[2,3-d]pyrimidin-3(4H)-yl)acetohydrazide (14)

Yield: $91 \%$ as white crystals, m.p. $246-248{ }^{\circ} \mathrm{C} ;{ }^{1} \mathrm{H}$ NMR $\left(400 \mathrm{MHz}, \mathrm{DMSO}-\mathrm{d}_{6}\right): \delta 9.36(\mathrm{~s}, 1 \mathrm{H}$, $\mathrm{D}_{2} \mathrm{O}$ exchangeable, $\left.\mathrm{NH}\right), 8.22\left(\mathrm{~s}, 1 \mathrm{H}, \mathrm{CH}_{\text {pyrimdine }}\right), 4.58\left(\mathrm{~s}, 2 \mathrm{H}, \mathrm{NCH}_{2}\right), 4.27\left(\mathrm{~s}, 2 \mathrm{H}, \mathrm{D}_{2} \mathrm{O}\right.$ exchangeable, $\left.\mathrm{NH}_{2}\right), 2.86$ (brs, $\left.2 \mathrm{H}, \mathrm{CH}_{2 \text { cyhex }}\right), 2.76$ (brs, $\left.2 \mathrm{H}, \mathrm{CH}_{2 \text { cyhex }}\right), 1.77-1.80\left(\mathrm{~m}, 4 \mathrm{H}, 2 \mathrm{CH}_{2 \text { cyhex }}\right) ;{ }^{13} \mathrm{C} \mathrm{NMR}$ (100 MHz, DMSO- $\left.d_{6}\right): \delta 166.55,162.13\left(2 \mathrm{C}=\mathrm{O}_{\text {(amide+pyrimidone) })}\right), 157.32,148.55,133.36,131.28,122.13$ (5 $\left.\mathrm{C}_{(1 \text { pyrimidine+4thiophene) })}\right), 46.85\left(\mathrm{NCH}_{2}\right), 25.77,25.00,22.88,22.24\left(4 \mathrm{CH}_{2 \text { cyhex }}\right)$; $\mathrm{CHN}$ calcd. for: $\mathrm{C}_{12} \mathrm{H}_{14} \mathrm{~N}_{4} \mathrm{O}_{2} \mathrm{~S}$ [278.33]: $\mathrm{C}, 51.78 ; \mathrm{H}, 5.07 ; \mathrm{N}, 20.13 ; \mathrm{S}, 11.52$; found: $\mathrm{C}, 51.80 ; \mathrm{H}, 5.17 ; \mathrm{N}, 20.11 ; \mathrm{S}, 11.55$.

Synthesis of (15): To a mixture of hydrazide $14(3.0 \mathrm{mmol})$ in $30 \mathrm{~mL}$ of dioxane, phenyl isothiocyanate $(3.7 \mathrm{mmol}$ ) was added, the reaction mixture was kept under reflux for $6 \mathrm{~h}$, concentrated, cooled, and left overnight. The formed ppt was collected and recrystallized from ethanol to give $\mathbf{1 5}$ as white crystals. 
2-(2-(4-Oxo-5,6,7,8-tetrahydrobenzo[4,5]thieno[2,3-d]pyrimidin-3(4H)-yl)acetyl)-N-phenylhydrazine-1carbothioamide (15)

Yield: $85 \%$, m.p. $155-156{ }^{\circ} \mathrm{C} ;{ }^{1} \mathrm{H}$ NMR (400 MHz, DMSO- $\left.d_{6}\right): \delta 10.56,9.77,9.33\left(3 \mathrm{~s}, 3 \mathrm{H}, \mathrm{D}_{2} \mathrm{O}\right.$ exchangeable, $3 \mathrm{NH}), 8.30$ (s, 1H, $\left.\mathrm{CH}_{\text {pyrimidone }}\right), 7.59(\mathrm{~d}, 2 \mathrm{H}, \mathrm{J} 8 \mathrm{~Hz}, 2 \mathrm{HAr}), 7.35(\mathrm{t}, 2 \mathrm{H}, 2 \mathrm{HAr}), 7.17-7.20$ (m, 1H, 1HAr ), 4.74 (s, 2H, NCH $), 2.81$ (brs, 2H, $\left.\mathrm{CH}_{2 \text { cyhex }}\right), 2.77$ (brs, $\left.2 \mathrm{H}, \mathrm{CH}_{2 \text { cyhex }}\right), 1.74-1.80$ (m, $\left.4 \mathrm{H}, 2 \mathrm{CH}_{2 \text { cyhex }}\right) ;{ }^{13} \mathrm{C}$ NMR (100 MHz, DMSO- $\left.d_{6}\right): \delta 181.06$ (C=S), 167.10, 162.5 (2 C=O pyrimidone+amide), $157.88,148.23,139.38,133.91,131.16,128.57,125.55,125.21,122.12\left(11 \mathrm{C}_{(1 \text { pyrimidone+4thiophene+6phenyl })}\right)$, $47.98\left(\mathrm{NCH}_{2}\right), 25.76,25.01,22.84,22.18\left(4 \mathrm{CH}_{2 \text { cyhex }}\right)$; $\mathrm{CHN}$ calcd. for: $\mathrm{C}_{19} \mathrm{H}_{19} \mathrm{~N}_{5} \mathrm{O}_{2} \mathrm{~S}_{2}$ [413.51]: C, 55.19; H, 4.63; N, 16.94; S, 15.51; found: C, 55.23; H, 4.60; N, 16.92; S, 15.50 .

General Procedures for Synthesis of Compounds (16) and (17): To a mixture of hydrazide $(3.0$ $\mathrm{mmol})$ in $30 \mathrm{~mL}$ of ethanol, the selected aldehyde or ketone $(3.3 \mathrm{mmol})$ was added and refluxed for 6 $\mathrm{h}$. Then, concentrated and left overnight, the formed ppt was recrystallized from ethanol to give $\mathbf{1 6}$ and 17.

(E)-N'-Benzylidene-2-(4-oxo-5,6,7,8-tetrahydrobenzo[4,5]thieno[2,3-d]pyrimidin-3(4H)-yl)acetohydrazide (16)

Yield: $52 \%$, m.p. $230{ }^{\circ} \mathrm{C} ;{ }^{1} \mathrm{H}$ NMR $\left(400 \mathrm{MHz}\right.$, DMSO- $\left.d_{6}\right): \delta 11.65\left(\mathrm{~s}, 1 \mathrm{H}, \mathrm{D}_{2} \mathrm{O}\right.$ exchangeable, $\left.\mathrm{NH}\right)$,

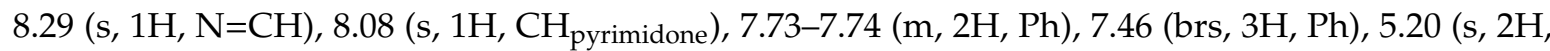
$\mathrm{NCH}_{2}$ ), 2.89 (brs, 2H, $\left.\mathrm{CH}_{2 \text { cyhex }}\right), 2.78$ (brs, $\left.2 \mathrm{H}, \mathrm{CH}_{2 \text { cyhex }}\right), 1.79-1.84\left(\mathrm{~m}, 4 \mathrm{H}, 2 \mathrm{CH}_{2 \text { cyhex }}\right) ;{ }^{13} \mathrm{C}$ NMR (100 MHz, DMSO- $\left.d_{6}\right): \delta 168.69,162.16$ (2 C=O amide+pyrimidone), 157.46, 148.61, 144.78, 134.37, 133.52,

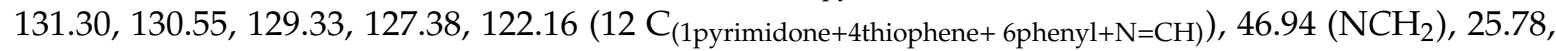
25.01, 22.87, 22.23 (4 $\left.\mathrm{CH}_{2 \text { cyhex }}\right)$; $\mathrm{CHN}$ calcd. for: $\mathrm{C}_{19} \mathrm{H}_{18} \mathrm{~N}_{4} \mathrm{O}_{2} \mathrm{~S}$ [366.44]: $\mathrm{C}, 62.28 ; \mathrm{H}, 4.95 ; \mathrm{N}, 15.29$; $\mathrm{S}$, 8.75; found: $\mathrm{C}, 62.30 ; \mathrm{H}, 4.92 ; \mathrm{N}, 15.31 ; \mathrm{S}, 8.73$.

(E)-2-(4-Oxo-5,6,7,8-tetrahydrobenzo[4,5]thieno[2,3-d]pyrimidin-3(4H)-yl)-N'-(1-phenylethylidene) acetohydrazide (17)

Yield: $50 \%$, m.p. $230{ }^{\circ} \mathrm{C} ;{ }^{1} \mathrm{H}$ NMR $\left(400 \mathrm{MHz}\right.$, DMSO- $\left.d_{6}\right): \delta 11.00\left(\mathrm{~s}, 1 \mathrm{H}, \mathrm{D}_{2} \mathrm{O}\right.$ exchangeable, NH), 8.30 (s, $1 \mathrm{H}, \mathrm{CH}_{\text {pyrimidone) }}, 7.80-7.86$ (m, 2H, 2HAr), 7.43 (brs, 3H, 3HAr), 5.23 (s, 2H, NCH $), 2.88$ (brs, $\left.2 \mathrm{H}, \mathrm{CH}_{2 \text { cyhex }}\right), 2.78$ (brs, $\left.2 \mathrm{H}, \mathrm{CH}_{2 \text { cyhex }}\right), 2.31\left(\mathrm{~s}, 3 \mathrm{H}, \mathrm{CH}_{3}\right), 1.79-1.81\left(\mathrm{~m}, 4 \mathrm{H}, 2 \mathrm{CH}_{2 \text { cyhex }}\right) ;{ }^{13} \mathrm{C} \mathrm{NMR}$ (100 MHz, DMSO- $\left.d_{6}\right): \delta 169.55,162.19$ (C=O amide+pyrimidone), 157.50, 149.44, 148.59, 138.32, 133.56, 131.29, 129.77, 128.90, 126.83, 126.58, $122.17\left(12 \mathrm{C}_{(\mathrm{N}=\mathrm{C}+1 \text { pyrimidone+4thiophene+6phenyl })}\right), 47.37\left(\mathrm{NCH}_{2}\right)$, 25.77, 25.00, 22.85, $22.21\left(4 \mathrm{CH}_{2 \text { cyhex }}\right), 14.09\left(\mathrm{CH}_{3}\right) ; \mathrm{CHN}$ calcd. for: $\mathrm{C}_{20} \mathrm{H}_{20} \mathrm{~N}_{4} \mathrm{O}_{2} \mathrm{~S}$ [380.46]: $\mathrm{C}, 63.14 ; \mathrm{H}$, 5.30; N, 14.73; S, 8.43; found: C, 63.12; H, 5.33; N, 14.75; S, 8.42.

Synthesis of (19): To hydrazide $14(3.0 \mathrm{mmol})$ in $30 \mathrm{~mL}$ of absolute ethanol containing aq. $\mathrm{KOH}$ $(6.0 \mathrm{mmol})$, carbon disulphide $(6.0 \mathrm{mmol})$ and the mixture was stirred at room temperature for $3 \mathrm{~h}$, then the solvent was removed on a water bath to get the yellow ppt of 18 , which was directly used for the next step without further purification. To potassium salt $18(3.0 \mathrm{mmol})$ in $10 \mathrm{~mL}$ of water, hydrazine hydrate $(6.0 \mathrm{mmol})$ was added and the mixture was refluxed for $5 \mathrm{~h}$, then cooled, diluted with water, and acidified by concentrated $\mathrm{HCl}$. The formed ppt was collected, dried, and recrystallized from ethanol to give white plates crystals from 19.

3-((4-Amino-5-thioxo-4,5-dihydro-1H-1,2,4-triazol-3-yl)methyl)-5,6,7,8-tetrahydrobenzo[4,5]thieno[2,3-d] pyrimidin-4(3H)-one (19)

Yield: $77 \%$, m.p. $269-271{ }^{\circ} \mathrm{C} ;{ }^{1} \mathrm{H}$ NMR $\left(400 \mathrm{MHz}, \mathrm{DMSO}-d_{6}\right): \delta 13.54(\mathrm{~s}, 1 \mathrm{H}$, exchangeable, $\mathrm{NH}), 8.38\left(\mathrm{~s}, 1 \mathrm{H}, \mathrm{CH}_{\text {pyrimidine }}\right), 5.61\left(\mathrm{~s}, 2 \mathrm{H}, \mathrm{D}_{2} \mathrm{O}\right.$ exchangeable, $\left.\mathrm{NH}_{2}\right), 5.25\left(\mathrm{~s}, 2 \mathrm{H}, \mathrm{NCH}_{2}\right), 2.87(\mathrm{t}, 2 \mathrm{H}$, $\left.\mathrm{CH}_{2 \text { cyhex }}\right), 2.77\left(\mathrm{t}, 2 \mathrm{H}, \mathrm{CH}_{2 \text { cyhex }}\right), 1.75-1.83\left(\mathrm{~m}, 4 \mathrm{H}, 2 \mathrm{CH}_{2 \text { cyhex }}\right) ;{ }^{13} \mathrm{C}$ NMR (100 MHz, DMSO- $\left.d_{6}\right)$ : $\delta 167.32\left(\mathrm{C}=\mathrm{S}_{\text {thioamide }}\right), 162.06\left(\mathrm{C}=\mathrm{O}_{\text {pyrimidone }}\right), 157.03,148.62,148.14,133.80,131.35,122.17$ (6 $\left.\mathrm{C}_{\text {(triazole+pyrimidine+4thiophene) }}\right), 40.2\left(\mathrm{NCH}_{2}\right), 25.75,25.01,22.84,22.19\left(4 \mathrm{CH}_{2 \text { cyhex }}\right) ; \mathrm{CHN}$ calcd. for: $\mathrm{C}_{13} \mathrm{H}_{14} \mathrm{~N}_{6} \mathrm{OS}_{2}$ [334.42]: $\mathrm{C}, 46.69 ; \mathrm{H}, 4.22 ; \mathrm{N}, 25.13 ; \mathrm{S}, 19.18$; found: $\mathrm{C}, 46.66 ; \mathrm{H}, 4.20 ; \mathrm{N}, 25.15 ; \mathrm{S}, 19.21$. 
Synthesis of (20): The benzothieno[2,3-d]pyrimidine 8 (4.5 mmol) was refluxed in $\mathrm{POCl}_{3}(20 \mathrm{~mL})$ for $3 \mathrm{~h}$. The mixture was cooled and added into ice/water. The formed ppt was filtered off, washed several times with water, dried, and recrystallized from EtOH to give colorless needle crystals.

4-Chloro-5,6,7,8-tetrahydrobenzo[4,5]thieno[2,3-d]pyrimidine (20)

Yield: $64 \%$, m.p. $110-112{ }^{\circ} \mathrm{C} ;{ }^{1} \mathrm{H}$ NMR (400 MHz, DMSO-d 6 ): $\delta 8.78$ (s, $1 \mathrm{H}, \mathrm{CH}_{\text {pyrimdine }}$ ), 2.98 (s, $\left.2 \mathrm{H}, \mathrm{CH}_{2 \text { cyhex }}\right), 2.88\left(\mathrm{~s}, 2 \mathrm{H}, \mathrm{CH}_{2 \text { cyhex }}\right), 1.85$ (s, 4H, $\left.2 \mathrm{CH}_{2 \text { cyhex }}\right) ;{ }^{13} \mathrm{C}$ NMR (100 MHz, DMSO- $\left.d_{6}\right): \delta 158.00$,

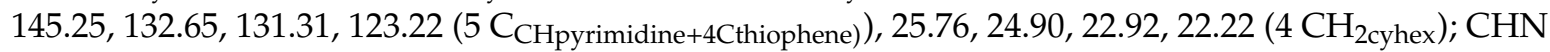
calcd. for: $\mathrm{C}_{10} \mathrm{H}_{9} \mathrm{ClN}_{2} \mathrm{~S}$ [224.70]: C, 53.45; H, 4.04; N, 12.47; S, 14.27; found: C, 53.47; H, 4.03; N, 12.49; S, 14.25 .

Synthesis of (21): A mixture 20 (3.6 mmol) and hydrazine hydrate $(0.03 \mathrm{mmol})$ in $35 \mathrm{~mL}$ of ethanol was refluxed for $5 \mathrm{~h}$, then concentrated to half, the formed solid product was filtered off, dried, and recrystallized from ethanol.

4-Hydrazineyl-5,6,7,8-tetrahydrobenzo[4,5]thieno[2,3-d]pyrimidine (21)

Yield: $85 \%$ as pale brown crystals, m.p. $175-176{ }^{\circ} \mathrm{C} ;{ }^{1} \mathrm{H}$ NMR $\left(400 \mathrm{MHz}, \mathrm{DMSO}-d_{6}\right): \delta 8.33(\mathrm{~s}, 2 \mathrm{H}$, $\mathrm{CH}_{\text {pyrimidine }}$ ), 7.81 (s, 1H, $\mathrm{D}_{2} \mathrm{O}$ exchangeable, $\left.\mathrm{NH}\right), 4.55\left(\mathrm{~s}, 2 \mathrm{H}, \mathrm{D}_{2} \mathrm{O}\right.$ exchangeable, $\left.\mathrm{NH}_{2}\right), 2.93$ (brs, $2 \mathrm{H}$, $\mathrm{CH}_{2 \text { cyhex }}$ ), 2.76 (brs, $\left.2 \mathrm{H}, \mathrm{CH}_{2 \text { cyhex }}\right), 1.80$ (brs, $\left.4 \mathrm{H}, 2 \mathrm{CH}_{2 \text { cyhex }}\right) ;{ }^{13} \mathrm{C}$ NMR $\left(100 \mathrm{MHz}, \mathrm{DMSO}-d_{6}\right): \delta 164.42$, 158.76 (2 $\left.\mathrm{C}_{\text {pyrimidine }}\right), 152.93,131.97,127.26,115.32$ ( $\left.4 \mathrm{C}_{\text {thiophene }}\right), 25.89,25.35,22.63,22.50\left(4 \mathrm{CH}_{2 \text { cyhex }}\right)$; CHN calcd. for: $\mathrm{C}_{10} \mathrm{H}_{12} \mathrm{~N}_{4} \mathrm{~S}$ [220.29]: C, 54.52; H, 5.49; N, 25.43; S, 14.55; found: C, 54.49; H, 5.51; N, 25.44; S, 14.57 .

Synthesis of (22): To hydrazide 21 (1.8 mmol) in $20 \mathrm{~mL}$ of absolute ethanol, benzoyl chloride $(2 \mathrm{mmol}$ ) was added, the reaction mixture was refluxed for $6 \mathrm{~h}$, then cooled. The formed solid product was filtered off and recrystallized from acetic acid.

$N^{\prime}-(5,6,7,8$-tetrahydrobenzo[4,5] thieno[2,3-d]pyrimidin-4-yl)benzohydrazide (22)

Yield: $68 \%$ brown crystals, m.p. $198-200{ }^{\circ} \mathrm{C} ;{ }^{1} \mathrm{H}$ NMR $\left(400 \mathrm{MHz}, \mathrm{DMSO}-d_{6}\right): \delta 9.64(\mathrm{~s}, 1 \mathrm{H}, \mathrm{NH})$, 8.29 (s, 2H, $\mathrm{CH}_{\text {pyrimdine+NH}}$ ), 7.59-7.60 (m, 5H, Ar), 3.22 (brs, 2H, $\mathrm{CH}_{2 \text { cyhex }}$ ), 2.97 (brs, 2H, $\mathrm{CH}_{2 \text { cyhex }}$ ), 1.91-1.95 (m, 4H, $\left.\left.2 \mathrm{CH}_{2 \text { cyhex }}\right) ;{ }^{13} \mathrm{C} \mathrm{NMR} \mathrm{(100} \mathrm{MHz,} \mathrm{DMSO-d}{ }_{6}\right): \delta 164.38$ (C=O), 153.33, 149.51, 138.69, $137.41,131.13,130.43,129.44,129.18,127.66,120.05\left(12 \mathrm{C}_{(2 \text { pyrimdine+ thiophene+phenyl) }}\right), 25.40,23.00,22.17$, 21.44 ( $4 \mathrm{CH}_{2 \text { cyhex }}$ ); $\mathrm{CHN}$ calcd. for: $\mathrm{C}_{17} \mathrm{H}_{16} \mathrm{~N}_{4} \mathrm{OS}$ [324.40]: C, 62.94; H, 4.97; N, 17.27; S, 9.88; found: C, 62.90; H, 4.96; N, 17.24; S, 9.85 .

The General Procedure for Synthesis of Compounds (23) and (24): A mixture of 21 (1.6 mmol) and the selected aldehyde or ketone $(2.0 \mathrm{mmol})$ in $20 \mathrm{~mL}$ of ethanol, was refluxed for $4 \mathrm{~h}$, on cooling, the solid product was filtered off, dried, and recrystallized from ethanol to give compounds 23 and 24 .

(E)-4-(2-benzylidenehydrazineyl)-5,6,7,8-tetrahydrobenzo[4,5]thieno[2,3-d]pyrimidine (23)

Yield: $80 \%$ pale brown needles, m.p. $108-110{ }^{\circ} \mathrm{C} ;{ }^{1} \mathrm{H}$ NMR $\left(400 \mathrm{MHz}, \mathrm{DMSO}-d_{6}\right): \delta 11.79$ (s, $1 \mathrm{H}, \mathrm{D}_{2} \mathrm{O}$ exchangeable, $\left.\mathrm{NH}\right), 8.40$ (s, 1H, $\left.\mathrm{CH}_{\text {pyrimidine }}\right), 7.94$ (brs, $\left.2 \mathrm{H}_{\text {phenyl }}\right), 7.80$ (s, 1H, N=CH-Ph), 7.39-7.46 (m, $3 \mathrm{H}_{\text {phenyl }}$ ), 3.01 (brs, $2 \mathrm{H}, \mathrm{CH}_{2 \text { cyhex }}$ ), 2.76 (brs, $2 \mathrm{H}, \mathrm{CH}_{2 \text { cyhex }}$ ), 1.80 (brs, $4 \mathrm{H}, 2 \mathrm{CH}_{2 \text { cyhex }}$ ); ${ }^{13} \mathrm{C}$ NMR (100 MHz, DMSO- $\left.d_{6}\right): \delta 157.81,153.32$ (2 C $\left._{\text {pyrimidine }}\right), 149.51,144.31,135.91,132.78,131.35,130.33$,

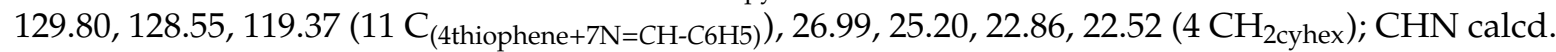
for: $\mathrm{C}_{17} \mathrm{H}_{16} \mathrm{~N}_{4} \mathrm{~S}$ [308.40]: C, 66.21; H, 5.23; N, 18.17; S, 10.40; found: C, 66.20; H, 5.26; N, 18.20; S, 10.20.

(E)-4-(2-(1-phenylethylidene)hydrazineyl)-5,6,7,8-tetrahydrobenzo[4,5] thieno[2,3-d]pyrimidine (24)

Yield: $85 \%$ red crystals, m.p. $178-180{ }^{\circ} \mathrm{C} ;{ }^{1} \mathrm{H}$ NMR $\left(400 \mathrm{MHz}, \mathrm{DMSO}-d_{6}\right): \delta 11.49\left(\mathrm{~s}, 1 \mathrm{H}, \mathrm{D}_{2} \mathrm{O}\right.$ exchangeable, $\mathrm{NH}$ ), 8.02 (brs, $\left.2 \mathrm{H}_{\text {phenyl }}\right), 7.78$ (s, 1H, $\left.\mathrm{CH}_{\text {pyrimidine }}\right), 7.41-7.43$ ( $\left.\mathrm{m}, 3 \mathrm{H}_{\text {phenyl }}\right), 3.04$ (brs, 2H, $\mathrm{CH}_{2 \text { cyhex }}$ ), 2.75 (brs, 2H, $\left.\mathrm{CH}_{2 \text { cyhex }}\right), 2.45$ (s, 3H, $\left.\mathrm{CH}_{3}\right), 1.81$ (brs, $\left.4 \mathrm{H}, 2 \mathrm{CH}_{2 \text { cyhex }}\right) ;{ }^{13} \mathrm{C} \mathrm{NMR}(100 \mathrm{MHz}$, DMSO- $\left.d_{6}\right): \delta 157.97,157.32,147.94,144.42,139.20,132.73,131.34,129.36,128.53,127.01,120.14(13 \mathrm{C}$ (4thiophene+6phenyl+2pyrimidine+N=C), 26.87, 25.18, 22.88, $22.65\left(4 \mathrm{CH}_{2 \text { cyhex }}\right), 14.68\left(\mathrm{CH}_{3}\right)$; $\mathrm{CHN}$ calcd. for: $\mathrm{C}_{18} \mathrm{H}_{18} \mathrm{~N}_{4} \mathrm{~S}$ [322.43]: C, 67.05; H, 5.63; N, 17.38; S, 9.94; found: C, 67.04; H, 5.66; N, 17.34; S, 9.99. 
Synthesis of (25) and (26): Hydrazino derivative 21 (2.7 mmol) was refluxed in a glacial acetic acid or formic acid ( $3.5 \mathrm{mmol}$ ) for $4 \mathrm{~h}$, then concentrated, cooled, and poured into cold water. The formed ppt was filtered off, washed with water, dried, and recrystallized from ethanol.

3-Methyl-8,9,10,11-tetrahydrobenzo[4,5]thieno[3,2-e][1,2,4]triazolo[4,3-c]pyrimidine (25)

Yield: $80 \%$, m.p. $180{ }^{\circ} \mathrm{C} ;{ }^{1} \mathrm{H}$ NMR $\left(400 \mathrm{MHz}, \mathrm{DMSO}-d_{6}\right): \delta 9.48$ (s, $\left.1 \mathrm{H}, \mathrm{CH}_{\text {pyrimidine }}\right), 3.05$ (brs, 2H, $\mathrm{CH}_{2 \text { cychex }}$ ), 2.91 (brs, 2H, $\mathrm{CH}_{2 \text { cychex }}$ ), 2.56 (s, 3H, $\left.\mathrm{CH}_{3}\right), 1.90$ (brs, $\left.4 \mathrm{H}, 2 \mathrm{CH}_{2 \text { cyhex }}\right) ;{ }^{13} \mathrm{C} \mathrm{NMR}(100 \mathrm{MHz}$, DMSO-d 6 ): $\delta 164.68,153.05,148.96$ (3 $\left.\mathrm{C}_{(2 \text { pyrimidine+1triazol) })}\right), 138.35,136.97,128.92,119.96$ (4 $\left.\mathrm{C}_{\text {thiophene }}\right)$, 25.33, 22.95, 22.15 (4 $\left.\mathrm{CH}_{2 \text { cyhex }}\right), 14.64\left(\mathrm{CH}_{3}\right)$; CHN calcd. for: $\mathrm{C}_{12} \mathrm{H}_{12} \mathrm{~N}_{4} \mathrm{~S}$ [344.32]: C, 58.99; $\mathrm{H}, 4.95 ; \mathrm{N}$, 22.93; S, 13.12; found: C, 58.98; H, 4.97; N, 22.90; S, 13.05.

\section{8,9,10,11-Tetrahydrobenzo[4,5]thieno[3,2-e][1,2,4] triazolo[4,3-c]pyrimidine (26)}

Yield: 65\%, m.p. $136{ }^{\circ} \mathrm{C} ;{ }^{1} \mathrm{H}$ NMR (400 MHz, DMSO- $\left.d_{6}\right): \delta 9.55$ (s, $\left.1 \mathrm{H}, \mathrm{CH}_{\text {pyrimdine }}\right), 8.60$ (s, 1H, $\left.\mathrm{CH}_{\text {triazole }}\right), 3.02-3.04\left(\mathrm{~m}, 2 \mathrm{H}, \mathrm{CH}_{2 \text { cyhex }}\right), 2.89-2.90\left(\mathrm{~m}, 2 \mathrm{H}, \mathrm{CH}_{2 \text { cyhex }}\right), 1.89-1.93(\mathrm{~m}, 4 \mathrm{H}, 2$ $\left.\mathrm{CH}_{2 \text { cyhex }}\right) ;{ }^{13} \mathrm{C} \mathrm{NM}\left(100 \mathrm{MHz}, \mathrm{DMSO}-d_{6}\right): \delta 155.09,152.86,148.26,138.69,137.48,128.86,120.14(7$ $\left.\mathrm{C}_{(1 \text { triazole+2pyrimdine+4thiophene })}\right), 25.28,25.22,22.89,22.10\left(4 \mathrm{CH}_{2 \text { cyhex }}\right) ; \mathrm{CHN}$ calcd. for: $\mathrm{C}_{11} \mathrm{H}_{10} \mathrm{~N}_{4} \mathrm{~S}$ [230.29]: C, 57.37; H, 4.38; N, 24.33; S, 13.92; found: C, 57.39; H, 4.40; N, 24.31; S, 13.90.

Synthesis of (27): A mixture of hydrazino derivative $21(2.7 \mathrm{mmol})$ and acetyl acetone $(2.8 \mathrm{mmol})$ in $20 \mathrm{~mL}$ abs. ethanol was refluxed for $6 \mathrm{~h}$ on cooling, a ppt is formed which was filtered and recrystallized from ethanol.

4-(3,5-Dimethyl-1H-pyrazol-1-yl)-5,6,7,8-tetrahydrobenzo[4,5]thieno[2,3-d]pyrimidine (27)

Yield: $67 \%$ yellow needles, m.p. $151-153{ }^{\circ} \mathrm{C} ;{ }^{1} \mathrm{H}$ NMR $\left(400 \mathrm{MHz}, \mathrm{DMSO}-d_{6}\right): \delta 8.97(\mathrm{~s}, 1 \mathrm{H}$, $\left.\mathrm{CH}_{\text {pyrimidine }}\right), 6.17$ (s, 1H, $\left.\mathrm{CH}_{\text {pyrazolyl }}\right), 2.92$ (brs, $\left.2 \mathrm{H}, \mathrm{CH}_{2 \text { cyhex }}\right), 2.21-2.30\left(\mathrm{~m}, 8 \mathrm{H}, 2 \mathrm{CH}_{3}+\mathrm{CH}_{2 \text { cyhex }}\right.$ ),

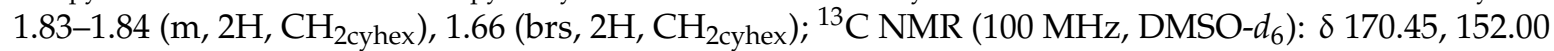
(2 $\left.\mathrm{C}_{\text {pyrimidine }}\right), 151.77,149.42,141.85,139.55,127.50,126.14,107.85$ (7 C (3pyrazole+4thiophene) $), 25.95,24.91$,

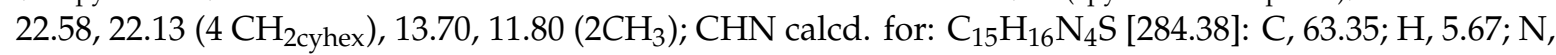
19.70; S, 11.28; found: C, 63.38; H, 5.65; N, 19.71; S, 11.26 .

Synthesis of (28)

Method A: To the hydrazino derivative $21(2.7 \mathrm{mmol})$ in $20 \mathrm{~mL}$ of ethanol containing aq. $\mathrm{KOH}$ $(6.0 \mathrm{mmol})$ carbon disulfide $(3.0 \mathrm{mmol})$ was added, the reaction mixture was refluxed for $6 \mathrm{~h}$, then cooled, diluted with water, and acidified with concentrated $\mathrm{HCl}$. A yellow ppt is formed, filtered off, washed with water, dried, and recrystallized from ethanol to give brown crystals.

Method B: A mixture of hydrazino derivative $21(1.8 \mathrm{mmol})$ and phenyl isothiocyanate $(2.0 \mathrm{mmol})$ in $10 \mathrm{~mL}$ of ethanol was refluxed for $6 \mathrm{~h}$. After that cooling, the solid product is formed, filtered off, and recrystallized from ethanol.

\section{8,9,10,11-Tetrahydrobenzo[4,5] thieno[3,2-e][1,2,4]triazolo[4,3-c]pyrimidine-3(2H)-thione (28)}

Yield: $85_{\mathrm{A}} \%, 65_{\mathrm{B}} \%$, m.p. $283-285{ }^{\circ} \mathrm{C} ;{ }^{1} \mathrm{H}$ NMR $\left(400 \mathrm{MHz}, \mathrm{DMSO}-d_{6}\right): \delta 14.62\left(\mathrm{~s}, 1 \mathrm{H}, \mathrm{D}_{2} \mathrm{O}\right.$ exchangeable, $\mathrm{NH}$ ), 8.87 (s, $1 \mathrm{H}, \mathrm{CH}_{\text {pyrimidine }}$ ), 2.90 (brs, $4 \mathrm{H}, 2 \mathrm{CH}_{2 \text { cyhex }}$ ), 1.88 (brs, $4 \mathrm{H}, 2 \mathrm{CH}_{2 \text { cyhex }}$ ); ${ }^{13} \mathrm{C}$ NMR (100 MHz, DMSO- $\left.d_{6}\right): \delta 160.56,151.28,143.19$ ( $\left.3 \mathrm{C}_{\text {(pyrimidine }+\mathrm{C}=\mathrm{S} \text { thioamide) }}\right), 138.78,135.69,129.59$, 117.23 (4 C thiophene ) , 25.14, 22.88, 22.05 (4 CH $\mathrm{CH}_{2 \text { cyhex }}$ ); $\mathrm{CHN}$ calcd. for: $\mathrm{C}_{11} \mathrm{H}_{10} \mathrm{~N}_{4} \mathrm{~S}_{2}$ [262.35]: C, 50.36; $\mathrm{H}$, 3.84; N, 21.36; S, 24.4; found: C, 50.32; H, 3.86; N, 21.32; S, 24.3.

The General Procedure for Synthesis of Compounds (29) and (30): The chloro derivative 20 $(1.8 \mathrm{mmol})$ was refluxed in sodium methoxide or sodium ethoxide (prepared from $0.23 \mathrm{~g}$ of sodium in $30 \mathrm{~mL}$ of ethanol or methanol) for $6 \mathrm{~h}$ after finishing and the solvent was concentrated. The formed solid product was filtered off and recrystallized from the water-ethanol mixture.

4-Methoxy-5,6,7,8-tetrahydrobenzo[4,5]thieno[2,3-d]pyrimidine (29)

Yield: $71.8 \%$ colorless needle crystals, m.p. $98-100{ }^{\circ} \mathrm{C} ;{ }^{1} \mathrm{H}$ NMR $\left(400 \mathrm{MHz}, \mathrm{DMSO}-d_{6}\right): \delta 8.55$ (s, $1 \mathrm{H}, \mathrm{CH}_{\text {pyrimidine }}$ ), 4.04 (s, 3H, $\mathrm{OCH}_{3}$ ), 2.86 (brs, 2H, $\mathrm{CH}_{2 \text { cyhex }}$ ), 2.80 (brs, 2H, $\mathrm{CH}_{2 \text { cyhex }}$ ), 1.82-1.81 (m, 
$\left.4 \mathrm{H}, 2 \mathrm{CH}_{2 \text { cyhex }}\right) ;{ }^{13} \mathrm{C}$ NMR (100 MHz, DMSO-d 6 ): $\delta 166.88,163.91$ (2 $\left.\mathrm{C}_{\text {pyrimidine }}\right), 152.67,135.01,127.49$, 118.56 ( $\left.4 \mathrm{C}_{\text {thiophene }}\right), 54.28\left(\mathrm{OCH}_{3}\right), 25.91,25.32,22.83,22.26\left(4 \mathrm{CH}_{2 \text { cyhex }}\right)$; $\mathrm{CHN}$ calcd. for: $\mathrm{C}_{11} \mathrm{H}_{12} \mathrm{~N}_{2} \mathrm{OS}$ [220.29]: C, 59.97; H, 6.35; N, 12.60; S, 14.42; found: C, 59.99; H, 6.34; N, 12.61; S, 14.38.

4-Ethoxy-5,6,7,8-tetrahydrobenzo[4,5]thieno[2,3-d]pyrimidine (30)

Yield: $67 \%$ white solid, m.p. $109{ }^{\circ} \mathrm{C} ;{ }^{1} \mathrm{H}$ NMR $\left(400 \mathrm{MHz}, \mathrm{DMSO}-\mathrm{d}_{6}\right): \delta 8.52$ (s, $\left.1 \mathrm{H}, \mathrm{CH}_{\text {pyrimidine }}\right)$, $4.52\left(\mathrm{q}, 2 \mathrm{H}, \mathrm{CH}_{2} \mathrm{CH}_{3}\right), 2.89-2.91\left(\mathrm{~m}, 2 \mathrm{H}, \mathrm{CH}_{2 \text { cyhex }}\right), 2.79-2.81\left(\mathrm{~m}, 2 \mathrm{H}, \mathrm{CH}_{2 \text { cyhex }}\right), 1.82-185(\mathrm{~m}, 4 \mathrm{H}, 2$ $\left.\mathrm{CH}_{2 \text { cyhex }}\right), 1.40\left(\mathrm{t}, 3 \mathrm{H}, \mathrm{CH}_{2} \mathrm{CH}_{3}\right) ;{ }^{13} \mathrm{C}$ NMR $\left(100 \mathrm{MHz}, \mathrm{DMSO}-\mathrm{d}_{6}\right): \delta 167,163.58$ (2 $\left.\mathrm{C}_{\text {pyrimidine }}\right), 152.70$, $134.88,127.59,118.57\left(4 \mathrm{C}_{\text {thiophene }}\right), 62.69\left(\mathrm{OCH}_{2}\right), 25.86,25.35,22.86,22.32\left(4 \mathrm{C}_{\text {cyhex }}\right), 14.66\left(\mathrm{CH}_{2} \mathrm{CH}_{3}\right)$; CHN calcd. for: $\mathrm{C}_{12} \mathrm{H}_{14} \mathrm{~N}_{2} \mathrm{OS}$ [234.31]: $\mathrm{C}, 61.51 ; \mathrm{H}, 6.02 ; \mathrm{N}, 11.96 ; \mathrm{S}, 13.68$; found: $\mathrm{C}, 61.53 ; \mathrm{H}, 6.05 ; \mathrm{N}$, $11.99 ; \mathrm{S}, 13.66$.

The General Procedure for Synthesis of Compounds (31-35): A mixture of chloro derivative $20(2.0 \mathrm{mmol})$ and the appropriate amine $(2.1 \mathrm{mmol})$ in $20 \mathrm{~mL}$ of ethanol was refluxed for $6 \mathrm{~h}$. The solvent was concentrated and on cooling a solid product is formed which was filtered off, dried, and recrystallized from ethanol to afford the corresponding compound 31-35.

$N$-(p-Tolyl)-5,6,7,8-tetrahydrobenzo[4,5]thieno[2,3-d]pyrimidin-4-amine (31)

Yield: $71 \%$, brown plates crystals, m.p. $140-142{ }^{\circ} \mathrm{C} ;{ }^{1} \mathrm{H}$ NMR $\left(400 \mathrm{MHz}, \mathrm{DMSO}-d_{6}\right): \delta 8.34(\mathrm{~s}, 1 \mathrm{H}$, $\mathrm{D}_{2} \mathrm{O}$ exchangeable, $\left.\mathrm{NH}\right), 7.98\left(\mathrm{~s}, 1 \mathrm{H}, \mathrm{CH}_{\text {pyrimidine }}\right), 7.55(\mathrm{~d}, J 8.0 \mathrm{~Hz}, 2 \mathrm{H}, 2 \mathrm{HAr}), 7.17(\mathrm{~d}, J 8 \mathrm{~Hz}, 2 \mathrm{H}, 2 \mathrm{CH}$, 2HAr), 3.12 (brs, $2 \mathrm{H}, \mathrm{CH}_{2 \text { cyhex }}$ ), 2.82 (brs, $2 \mathrm{H}, \mathrm{CH}_{2 \text { cyhex }}$ ), 2.30 (s, 3H, $\left.\mathrm{CH}_{3}\right), 1.86$ (brs, $4 \mathrm{H}, 2 \mathrm{CH}_{2 \text { cyhex }}$ ); ${ }^{13} \mathrm{C}$ NMR $\left(100 \mathrm{MHz}, \mathrm{DMSO}-d_{6}\right): \delta 166.06,155.51$ (2 $\left.\mathrm{C}_{\text {pyrimidine }}\right), 152.55,137.02,133.20,132.96,129.29$,

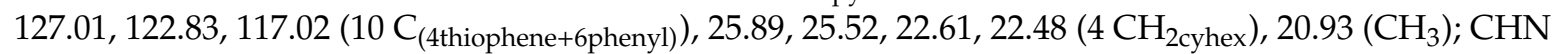
calcd. for: $\mathrm{C}_{17} \mathrm{H}_{17} \mathrm{~N}_{3} \mathrm{~S}$ [295.40]: $\mathrm{C}, 69.12 ; \mathrm{H}, 5.80 ; \mathrm{N}, 14.22 ; \mathrm{S}, 10.85$; found: $\mathrm{C}, 69.10 ; \mathrm{H}, 5.81 ; \mathrm{N}, 14.25$; S, 10.79 .

\section{N-Benzyl-5,6,7,8-tetrahydrobenzo[4,5]thieno[2,3-d]pyrimidin-4-amine (32)}

Yield: $65.5 \%$, m.p. $162-164{ }^{\circ} \mathrm{C} ;{ }^{1} \mathrm{H}$ NMR (400 MHz, DMSO-d 6 ): $\delta 8.54(\mathrm{~d}, 1 \mathrm{H}, J 8.0 \mathrm{~Hz}$, phenyl), $8.43\left(\mathrm{~s}, 1 \mathrm{H}, \mathrm{CH}_{\text {pyrimidine }}\right), 8.13\left(\mathrm{~s}, 1 \mathrm{H}, \mathrm{D}_{2} \mathrm{O}\right.$ exchangeable, $\left.\mathrm{NH}\right), 6.98-7.11(\mathrm{~m}, 4 \mathrm{H}$, phenyl), $3.92(\mathrm{~s}, 2 \mathrm{H}$, $\left.\mathrm{NHCH}_{2} \mathrm{Ph}\right), 3.07-3.09\left(\mathrm{~m}, 2 \mathrm{H}, \mathrm{CH}_{2 \text { cyhex }}\right), 2.82-2.84\left(\mathrm{~m}, 2 \mathrm{H}, \mathrm{CH}_{2 \text { cyhex }}\right), 1.87-1.94\left(\mathrm{~m}, 4 \mathrm{H}, 2 \mathrm{CH}_{2 \text { cyhex }}\right.$ ); ${ }^{13} \mathrm{C}$ NMR (100 MHz, DMSO-d $\left.{ }_{6}\right): \delta 165.60,154.84$ (2 $\left.\mathrm{C}_{\text {pyrimidine }}\right), 152.71,149.38,134.05,128.79,126.24$, 123.66, 121.03, 117.15, 111.42 (10 C (6phenyl+4thiophene) $)$, 56.77 (CH2-NHBn), 25.94, 25.49, 22.58, 22.40 (4 $\mathrm{CH}_{2 \text { cyhex }}$ ); $\mathrm{CHN}$ calcd. for: $\mathrm{C}_{17} \mathrm{H}_{17} \mathrm{~N}_{3} \mathrm{~S}$ [295.40]: $\mathrm{C}, 69.12 ; \mathrm{H}, 5.80 ; \mathrm{N}, 14.22 ; \mathrm{S}, 10.85$; found: $\mathrm{C}, 69.10 ; \mathrm{H}$, $5.81 ; \mathrm{N}, 14.25 ; \mathrm{S}, 10.79$.

4-((5,6,7,8-Tetrahydrobenzo[4,5]thieno[2,3-d]pyrimidin-4-yl)amino)benzoic acid (33)

Yield: $88 \%$ yellow crystals, m.p. $269-271{ }^{\circ} \mathrm{C} ;{ }^{1} \mathrm{H}$ NMR (400 MHz, DMSO- $\left.d_{6}\right): 8.50(\mathrm{~s}, 2 \mathrm{H}$, $\left.\mathrm{CH}_{\text {pyrimidine }}+\mathrm{COOH}\right), 7.93(\mathrm{~d}, 2 \mathrm{H}, J 8.0 \mathrm{HZ}, 2 \mathrm{HAr}), 7.82(\mathrm{~d}, 2 \mathrm{H}, J 8.0 \mathrm{~Hz}, 2 \mathrm{HAr}), 5.09\left(\mathrm{~s}, 1 \mathrm{H}, \mathrm{D}_{2} \mathrm{O}\right.$ exchangeable, $\mathrm{NH}$ ), 3.16 (brs, $2 \mathrm{H}, \mathrm{CH}_{2 \text { cyhex }}$ ), 2.86 (brs, $2 \mathrm{H}, \mathrm{CH}_{2 \text { cyhex }}$ ), 1.92 (brs, $4 \mathrm{H}, 2 \mathrm{CH}_{2 \text { cyhex }}$ ); ${ }^{13} \mathrm{C}$ NMR (100 MHz, DMSO- $\left.d_{6}\right): \delta 167.43(\mathrm{C}=\mathrm{O}), 165.69,154.72$ (2 $\left.\mathrm{C}_{\text {pyrimidine }}\right), 151.97,143.99,134.49,130.50$, $127.13,125.30,120.89,118.14\left(10 \mathrm{C}_{(4 \text { thiophene+ 6phenyl) }}\right)$, 25.71, 25.59, 22.60, $22.40\left(4 \mathrm{CH}_{2 \text { cyhex }}\right)$; $\mathrm{CHN}$ calcd. for: $\mathrm{C}_{17} \mathrm{H}_{15} \mathrm{~N}_{3} \mathrm{O}_{2} \mathrm{~S}$ [325.39]: $\mathrm{C}, 62.75 ; \mathrm{H}, 4.65 ; \mathrm{N}, 12.91 ; \mathrm{S}, 9.85$; found: $\mathrm{C}, 62.80 ; \mathrm{H}, 4.60 ; \mathrm{N}, 12.93 ; \mathrm{S}, 9.87$. 1-(4-((5,6,7,8-Tetrahydrobenzo[4,5]thieno[2,3-d]pyrimidin-4-yl)amino)phenyl)ethan-1-one (34)

Yield: $67 \%$ brown crystals, m.p. $173-175{ }^{\circ} \mathrm{C} ;{ }^{1} \mathrm{H}$ NMR $\left(400 \mathrm{MHz}, \mathrm{DMSO}-\mathrm{d}_{6}\right): \delta 8.49\left(\mathrm{~s}, 1 \mathrm{H}, \mathrm{D}_{2} \mathrm{O}\right.$

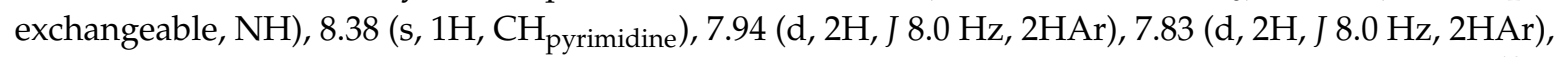
3.14 (brs, $\left.2 \mathrm{H}, \mathrm{CH}_{2 \text { cyhex }}\right), 2.84$ (brs, $\left.2 \mathrm{H}, \mathrm{CH}_{2 \text { cyhex }}\right), 2.54$ (s, $\left.3 \mathrm{H}, \mathrm{OCH}_{3}\right), 1.87$ (brs, $4 \mathrm{H}, 2 \mathrm{CH}_{2 \text { cyhex }}$ ); ${ }^{13} \mathrm{C}$

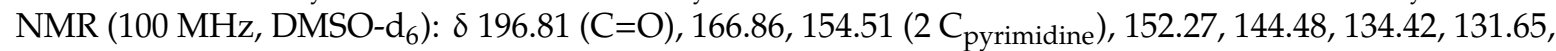
$129.55,126.94,120.42,118.17$ (10 C (6phenyl+4thiophene) $), 26.81\left(\mathrm{CH}_{3}\right), 25.7,25.59,22.60,22.42\left(4 \mathrm{CH}_{2 \text { cyhex }}\right)$; CHN calcd. for: $\mathrm{C}_{18} \mathrm{H}_{17} \mathrm{~N}_{3} \mathrm{OS}$ [323.41]: $\mathrm{C}, 66.85 ; \mathrm{H}, 5.30 ; \mathrm{N}, 12.99 ; \mathrm{S}, 9.91$; found: $\mathrm{C}, 66.82 ; \mathrm{H}, 5.31 ; \mathrm{N}$, 12.96; S, 9.90 . 


\section{1,2,3,4-Tetrahydro-9H-benzo[4',5']thieno[2',3':4,5]pyrimido[6,1-b]quinazolin-9-one (35)}

Yield: $70 \%$ yellow crystals, m.p. $285^{\circ} \mathrm{C} ;{ }^{1} \mathrm{H}$ NMR $\left(400 \mathrm{MHz}, \mathrm{DMSO}-d_{6}\right): \delta 9.34\left(\mathrm{~s}, 1 \mathrm{H}, \mathrm{CH}_{\text {pyrimdine }}\right)$, $8.35\left(\mathrm{~d}, 1 \mathrm{H}_{\text {phenyl }}\right), 7.96\left(\mathrm{t}, 1 \mathrm{H}_{\text {phenyl }}\right), 7.78\left(\mathrm{~d}, 1 \mathrm{H}_{\text {phenyl }}\right), 7.57\left(\mathrm{t}, 1 \mathrm{H}_{\text {phenyl }}\right) 2.91,1.90\left(4 \mathrm{CH}_{2 \text { cyhex }}\right) ; \mathrm{CHN}$ calcd. for: $\mathrm{C}_{17} \mathrm{H}_{13} \mathrm{~N}_{3} \mathrm{OS}$ [307.37]: $\mathrm{C}, 66.43 ; \mathrm{H}, 4.26 ; \mathrm{N}, 13.67 ; \mathrm{S}, 10.43$; found: $\mathrm{C}, 66.40 ; \mathrm{H}, 4.24 ; \mathrm{N}, 13.69$; $\mathrm{S}, 10.40$.

\subsection{Biological Experimental Assays (Full Protocols, see Supplementary Materials)}

\subsubsection{In Vitro}

In vitro work regarding cell culturing, cytotoxic screening using the MTT assay, and the $\mathrm{IC}_{50}$ calculations were made according to Mosmann 1983 (see Supplementary Materials) [38].

\subsubsection{Flow Cytometry}

All flow cytometry including FITC/Annexin-V-FITC/PI differential apoptosis/necrosis assessment, DNA content-flow cytometry aided cell cycle analysis, and acridine orange quantitative autophagy assessment were made according to Nafie et al., 2020 [39].

\subsubsection{In Silico Molecular Docking}

All in silico studies including ligand optimization, protein preparation, and molecular docking calculation were investigated followed by the reported [40].

\subsubsection{Bioinformatics}

Bioinformatics study (in silico and bioactivity prediction) of the most active compounds were calculated using a set of software's including MolSoft, Molinspiration [41], and SwissADME [42] websites as previously described by Youssef et al., 2020 [37].

\subsubsection{In Vivo (SEC) Model}

Experiment design and methodology including tumor volume and percentage of tumor inhibition were summarized in Figure 7.

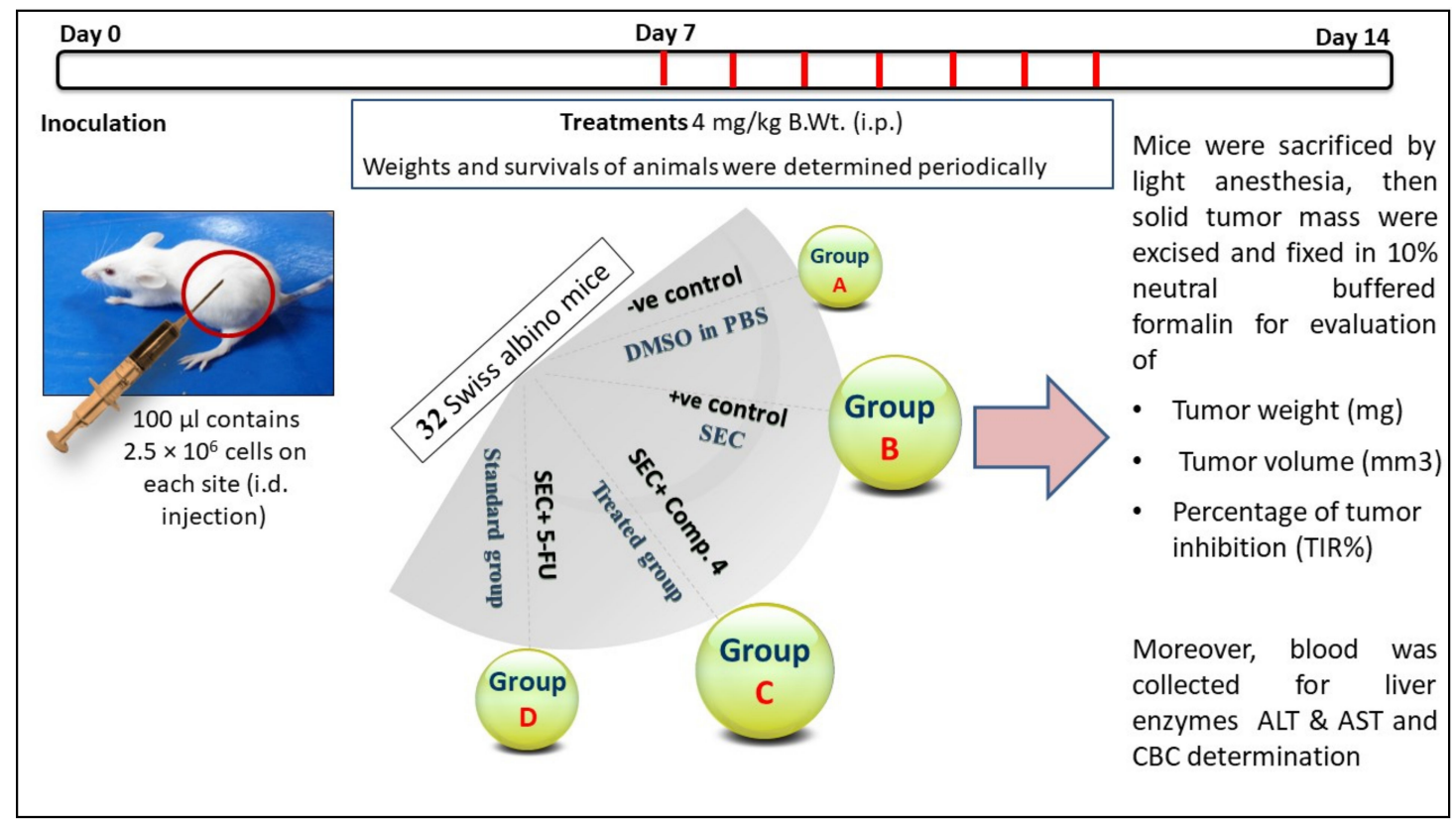

Figure 7. Summarized methodology of Solid Ehrlich Carcinoma (SEC)-bearing mice in vivo. 


\subsubsection{Statistical Analysis}

Data were represented by the value of the mean for three different replicates, with the standard error of the mean (mean \pm SEM). All statistical analysis was done as using GraphPad Prism software version 7.0. The statistical difference between two groups was examined using the unpaired $t$-test. The significance level was set at $p<0.05$.

\section{Conclusions}

In conclusion, approximately 33 compounds were synthesized and characterized. The target compounds were evaluated in vitro against HepG-2 and MCF-7 cancer cell lines. Hit 4 was found to be the most active, and the cell cycle analysis showed that this lead induces apoptosis. Moreover, the in vivo study demonstrates that our target significantly reduces the tumor mass. The in silico molecular docking shows the binding of 4 as an agonist for JAK2 inhibitors.

Supplementary Materials: The following are available online, Full protocols for the biological assays; Figure S1-S87 copies of the HNMR and CNMR spectrum of the synthesized compounds.

Author Contributions: Conceptualization, E.H.E., A.T.A.B., and E.M.G.; synthesis and characterization, M.S.A.G.H., E.H.E., A.T.A.B., and E.M.G.; in vivo, in silico, bioinformatics experiments and flow cytometric analyses discussion, M.S.N.; writing original manuscript, A.T.A.B., M.S.N., and A.B.; revision and editing, A.T.A.B., M.S.N., and A.B. All authors have read and agree to the published version of the manuscript.

Funding: Researchers Supporting Project, King Saud University.

Acknowledgments: The authors would like to extend their sincere appreciation to the Researchers Supporting Project (RSP-2019/64), King Saud University, Riyadh, Saudi Arabia.

Conflicts of Interest: The authors declare no conflict of interest.

\section{References}

1. Ovaa, H.; Kuijl, C.; Neefjes, J. Recent and new targets for small molecule anti-cancer agents. Drug Discov. Today Technol. 2009, 6, e3-e11. [CrossRef] [PubMed]

2. Bray, F.; Ferlay, J.; Soerjomataram, I.; Siegel, R.L.; Torre, L.A.; Jemal, A. Global cancer statistics 2018: GLOBOCAN estimates of incidence and mortality worldwide for 36 cancers in 185 countries. CA A Cancer J. Clin. 2018, 68, 394-424. [CrossRef] [PubMed]

3. Kiss, R.; Sayeski, P.P.; Keserú, G.M. Recent developments on JAK2 inhibitors: A patent review. Expert Opin. Ther. Patents 2010, 20, 471-495. [CrossRef] [PubMed]

4. Verma, A.; Kambhampati, S.; Parmar, S.; Platanias, L.C. Jak family of kinases in cancer. Cancer Metastasis Rev. 2003, 22, 423-434. [CrossRef] [PubMed]

5. Dinakaran, V.S.; Bomma, B.; Srinivasan, K.K. Fused pyrimidines: The heterocycle of diverse biological and pharmacological significance. Der Pharma Chem. 2012, 4, 255-265.

6. Mavrova, A.T.; Dimov, S.; Yancheva, D.; Rangelov, M.; Wesselinova, D.; Tsenov, J.A. Synthesis, anticancer activity and photostability of novel 3-ethyl-2-mercapto-thieno[2,3- d ]pyrimidin-4( $3 \mathrm{H}$ )-ones. Eur. J. Med. Chem. 2016, 123, 69-79. [CrossRef]

7. Rheault, T.R.; Caferro, T.R.; Dickerson, S.H.; Donaldson, K.H.; Gaul, M.D.; Goetz, A.S.; Mullin, R.J.; McDonald, O.B.; Petrov, K.G.; Rusnak, D.W.; et al. Thienopyrimidine-based dual EGFR/ErbB-2 inhibitors. Bioorg. Med. Chem. Lett. 2009, 19, 817-820. [CrossRef]

8. Bánhegyi, P.; Kéri, G.; Örfi, L.; Szekélyhidi, Z.; Wáczek, F. Vichem Chemie Kutato Kft, Tricyclic benzo [4, 5] thieno-[2, 3-d] pyrimidine-4-yl-amin Derivatives, Their Salts, Process for Producing the Compounds and Their Pharmaceutical Use. U.S. Patent 8,802,849, 12 August 2014.

9. Wu, C.-H.; Coumar, M.S.; Chu, C.-Y.; Lin, W.-H.; Chen, Y.-R.; Chen, C.-T.; Shiao, H.-Y.; Rafi, S.; Wang, S.-Y.; Hsu, H.; et al. Design and Synthesis of Tetrahydropyridothieno[2,3-d]pyrimidine Scaffold Based Epidermal Growth Factor Receptor (EGFR) Kinase Inhibitors: The Role of Side Chain Chirality and Michael Acceptor Group for Maximal Potency. J. Med. Chem. 2010, 53, 7316-7326. [CrossRef]

10. Li, H.; Chen, C.; Xu, S.; Cao, X. Synthesis and Bioevaluation of Thieno[2,3-d]pyrimidinone Derivatives as Potential Tumor Cell Growth Inhibitors. J. Chem. 2013, 2013, 1-6. [CrossRef] 
11. Abbas, S.E.; Gawad, N.M.A.; George, R.F.; Akar, Y.A. Synthesis, antitumor and antibacterial activities of some novel tetrahydrobenzo[4,5]thieno[2,3-d]pyrimidine derivatives. Eur. J. Med. Chem. 2013, 65, 195-204. [CrossRef]

12. Dai, Y.; Guo, Y.; Frey, R.R.; Ji, Z.; Curtin, M.L.; Ahmed, A.A.; Albert, D.H.; Arnold, L.; Arries, S.S.; Barlozzari, T.; et al. Thienopyrimidine Ureas as Novel and Potent Multitargeted Receptor Tyrosine Kinase Inhibitors. J. Med. Chem. 2005, 48, 6066-6083. [CrossRef] [PubMed]

13. Noronha, G.; Mak, C.C.; Cao, J.; Chow, C.; Daneprovskaia, E.; Renick, J. Anilinopyrimidines as Jak Kinase Inhibitors. Patent WO2009046416A1, 9 April 2009.

14. Zhang, W.; Ma, T.; Li, S.; Yang, Y.; Guo, J.; Kong, L.; Kong, L. Antagonizing STAT3 activation with benzo[b]thiophene 1, 1-dioxide based small molecules. Eur. J. Med. Chem. 2017, 125, 538-550. [CrossRef]

15. Chen, H.; Yang, Z.; Ding, C.; Xiong, A.; Wild, C.; Wang, L.; Ye, N.; Cai, G.; Flores, R.M.; Ding, Y.; et al. Discovery of potent anticancer agent HJC0416, an orally bioavailable small molecule inhibitor of signal transducer and activator of transcription 3 (STAT3). Eur. J. Med. Chem. 2014, 82, 195-203. [CrossRef]

16. Abdelrahman, S.; El-Gohary, N.S.; Elbendary, E.; El-Ashry, S.M.; Shaaban, M.I. Synthesis, antimicrobial, antiquorum-sensing, antitumor and cytotoxic activities of new series of cyclopenta(hepta)[ $b$ ]thiophene and fused cyclohepta[ b ]thiophene analogs. Eur. J. Med. Chem. 2017, 140, 200-211. [CrossRef] [PubMed]

17. Ismail, M.M.; Kamel, M.M.; Mohamed, L.W.; Faggal, S.I.; Galal, M.A. Synthesis and Biological Evaluation of Thiophene Derivatives as Acetylcholinesterase Inhibitors. Molecules 2012, 17, 7217-7231. [CrossRef] [PubMed]

18. Scheich, C.; Puetter, V.; Schade, M. Novel small molecule inhibitors of MDR Mycobacterium tuberculosis by NMR fragment screening of antigen 85C. J. Med. Chem. 2010, 53, 8362-8836. [CrossRef]

19. Bassetto, M.; Leyssen, P.; Neyts, J.; Yerukhimovich, M.M.; Frick, D.N.; Brancale, A. Computer-aided identification, synthesis and evaluation of substituted thienopyrimidines as novel inhibitors of HCV replication. Eur. J. Med. Chem. 2016, 123, 31-47. [CrossRef]

20. Rashad, A.; Shamroukh, A.; Abdel-Megeid, R.E.; Mostafa, A.; El-Shesheny, R.; Kandeil, A.; Ali, M.A.; Banert, K. Synthesis and screening of some novel fused thiophene and thienopyrimidine derivatives for anti-avian influenza virus (H5N1) activity. Eur. J. Med. Chem. 2010, 45, 5251-5257. [CrossRef]

21. Deka, S.; Mohan, S.; Saravanan, J.; Kakati, M.; Talukdar, A.; Sahariah, B.; Dey, B.; Sarma, R. Synthesis, characterization and in-vitro antiinflammatory activity of some novel thiophenes. J. Med. Sci. 2012, 5, 159-163. [CrossRef]

22. Kuncha, M.; Shireesha, B.; Naidu, V.G.M.; Ramakrishna, S.; Narsaiah, B.; Rao, A.R.; Diwan, P.V. Anti-inflammatory potential of thienopyridines as possible alternative to NSAIDs. Eur. J. Pharmacol. 2012, 678, 48-54. [CrossRef]

23. Mabkhot, Y.N.; Kheder, N.A.; Barakat, A.; Choudhary, M.I.; Yousuf, S.; Frey, W. Synthesis, Antimicrobial, Anti-Cancer and Molecular Docking of Two Novel Hitherto Unreported Thiophenes. RSC Adv. 2016, 6, 63724-63729. [CrossRef]

24. Dewal, M.B.; Wani, A.S.; Vidaillac, C.; Oupicky, D.; Rybak, M.J.; Firestine, S.M. Thieno[2,3-d]pyrimidinedione derivatives as antibacterial agents. Eur. J. Med. Chem. 2012, 51, 145-153. [CrossRef] [PubMed]

25. Wang, W.; Shangguan, S.; Qiu, N.; Hu, C.; Zhang, L.; Hu, Y. Design, synthesis and biological evaluation of novel 3,4,5-trisubstituted aminothiophenes as inhibitors of p53-MDM2 interaction, Part 1. Bioorg. Med. Chem. 2013, 21, 2879-2885. [CrossRef]

26. Stephens, C. Synthesis and antiviral/antitumor evaluation of 2-amino- and 2-carboxamido-3arylsulfonylthiophenes and related compounds as a new class of diarylsulfones. Bioorg. Med. Chem. 2001, 9, 1123-1132. [CrossRef]

27. Titchenell, P.M.; Showalter, H.D.H.; Pons, J.-F.; Barber, A.J.; Jin, Y.; Antonetti, D.A. Synthesis and structure-activity relationships of 2-amino-3-carboxy-4-phenylthiophenes as novel atypical protein kinase C inhibitors. Bioorg. Med. Chem. Lett. 2013, 23, 3034-3038. [CrossRef] [PubMed]

28. Perspicace, E.; Jouan-Hureaux, V.; Ragno, R.; Ballante, F.; Sartini, S.; La Motta, C.; Da Settimo, F.; Chen, B.; Kirsch, G.; Schneider, S.; et al. Design, synthesis and biological evaluation of new classes of thieno[3,2-d]pyrimidinone and thieno[1,2,3]triazine as inhibitor of vascular endothelial growth factor receptor-2 (VEGFR-2). Eur. J. Med. Chem. 2013, 63, 765-781. [CrossRef]

29. Kassab, A.E.; Gedawy, E.M. ChemInform Abstract: Synthesis and Anticancer Activity of Novel 2-Pyridyl Hexahydrocyclooctathieno[2,3-d]pyrimidine Derivatives. ChemInform 2013, 44, 224-230. [CrossRef] 
30. Kattan, S.W.; Nafie, M.S.; Elmgeed, G.A.; Alelwani, W.; Badar, M.; Tantawy, M.A. Molecular docking, anti-proliferative activity and induction of apoptosis in human liver cancer cells treated with androstane derivatives: Implication of PI3K/AKT/mTOR pathway. J. Steroid. Biochem. 2020, 198, 105604. [CrossRef]

31. Lipinski, C.A.; Lombardo, F.; Dominy, B.W.; Feeney, P.J. Experimental and computational approaches to estimate solubility and permeability in drug discovery and development settings. Adv. Drug Deliv. Rev. 1997, 23, 3-25. [CrossRef]

32. Lipinski, C. Lead- and drug-like compounds: The rule-of-five revolution. Drug Discov. Today Technol. 2004, 1, 337-341. [CrossRef]

33. Leeson, P.D.; Springthorpe, B. The influence of drug-like concepts on decision-making in medicinal chemistry. Nat. Rev. Drug Discov. 2007, 6, 881-890. [CrossRef] [PubMed]

34. Clark, D.E.; Pickett, S.D. Computational methods for the prediction of 'drug-likeness'. Drug Discov. Today 2000, 5, 49-58. [CrossRef]

35. Ghose, A.K.; Herbertz, T.; Hudkins, R.L.; Dorsey, B.D.; Mallamo, J.P. Knowledge-Based, Central Nervous System (CNS) Lead Selection and Lead Optimization for CNS Drug Discovery. ACS Chem. Neurosci. 2011, 3 , 50-68. [CrossRef] [PubMed]

36. Veber, D.F.; Johnson, S.R.; Cheng, H.-Y.; Smith, B.R.; Ward, K.W.; Kopple, K.D. Molecular Properties That Influence the Oral Bioavailability of Drug Candidates. J. Med. Chem. 2002, 45, 2615-2623. [CrossRef] [PubMed]

37. Youssef, E.; El-Moneim, M.A.; Fathalla, W.; Nafie, M.S. Design, synthesis and antiproliferative activity of new amine, amino acid and dipeptide-coupled benzamides as potential sigma-1 receptor. J. Iran. Chem. Soc. 2020, 1-18. [CrossRef]

38. Mosmann, T. Rapid colorimetric assay for cellular growth and survival: Application to proliferation and cytotoxicity assays. J. Immunol. Methods 1983, 65, 55-63. [CrossRef]

39. Nafie, M.S.; Arafa, K.; Sedky, N.K.; Alakhdar, A.A.; Arafa, R.K. Triaryl dicationic DNA minor-groove binders with antioxidant activity display cytotoxicity and induce apoptosis in breast cancer. Interact Biol. Chem. 2020, 324, 109087. [CrossRef]

40. Nafie, M.S.; Tantawy, M.A.; Elmgeed, G.A. Screening of different drug design tools to predict the mode of action of steroidal derivatives as anti-cancer agents. Steroids 2019, 152, 108485. [CrossRef]

41. Salem, M.G.; Aziz, Y.M.A.; Elewa, M.; Elshihawy, H.A.; Said, M.M. Synthesis and molecular modeling of novel non-sulfonylureas as hypoglycemic agents and selective ALR2 inhibitors. Bioorg. Med. Chem. 2019, 27, 3383-3389. [CrossRef]

42. Daina, A.; Michielin, O.; Zoete, V. SwissADME: A free web tool to evaluate pharmacokinetics, drug-likeness and medicinal chemistry friendliness of small molecules. Sci. Rep. 2017, 7, 42717. [CrossRef]

Sample Availability: Samples of the compounds 1-35 are available from the authors.

(C) 2020 by the authors. Licensee MDPI, Basel, Switzerland. This article is an open access article distributed under the terms and conditions of the Creative Commons Attribution (CC BY) license (http://creativecommons.org/licenses/by/4.0/). 